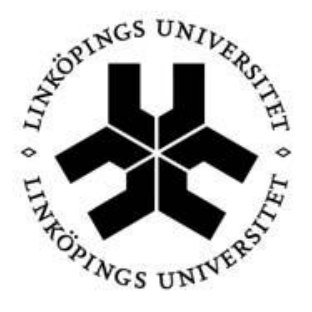

\title{
Linköpings universitet
}

Department of Management and Engineering

MA in International and European Relations

\section{MASTER THESIS}

\section{"GLOBAL GOVERNANCE OF MIGRATION"}

ISRN: LIU-IEI-FIL-A--11/01030--SE

Sirus Rustamov

Master Thesis, 30 ECTS

Supervisor: Ronnie Hjorth

Linköping, Sweden

May, 2011 


\section{CONTENTS}

\section{Acknowledgements}

\section{Acronyms}

\section{Abstract}

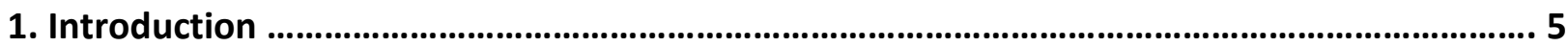

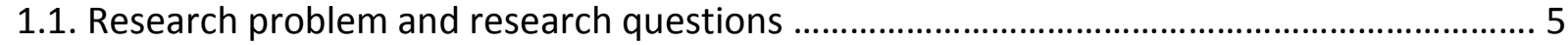

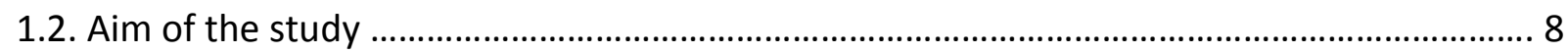

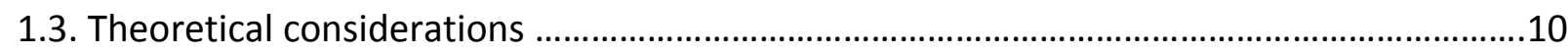

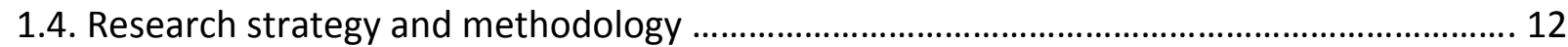

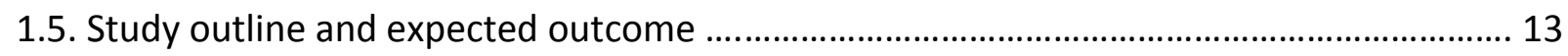

2. Existing Types of the Global Governance of Migration ....................................................... 15

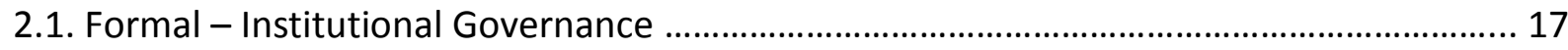

A) Within the United Nations system ......................................................................17

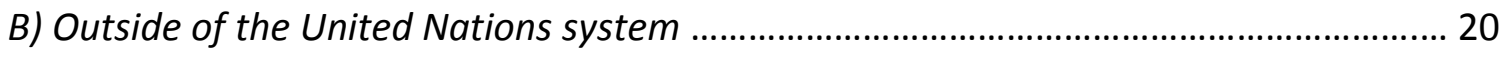

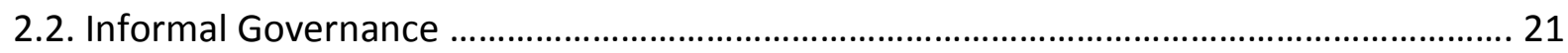

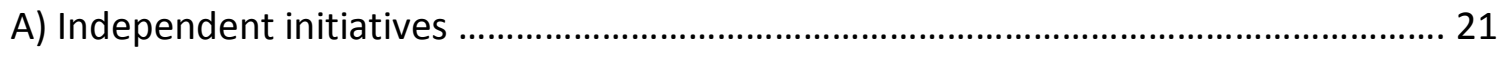

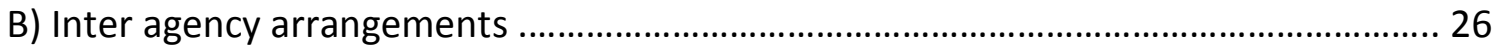

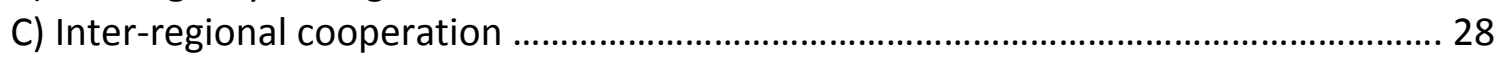

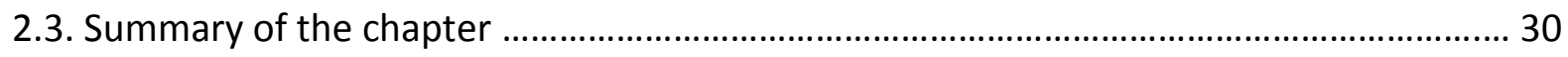

3. Civil Society Actors in the Global Governance of Migration .............................................. 33

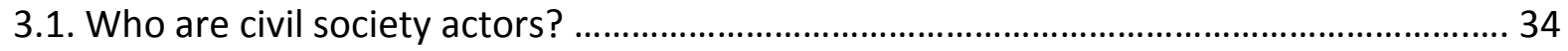

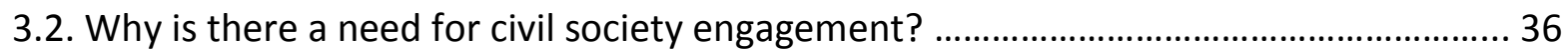

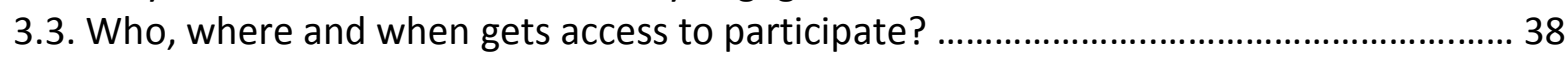

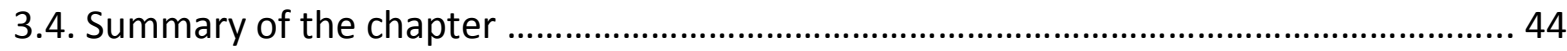

4. Comparison with Other Policy Areas ............................................................................ 46

4.1. Lessons to be learnt from the Global Governance

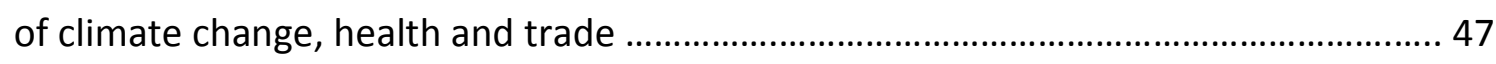

5. Theoretical Implications of International Migration Politics and Analysis ........................ 53

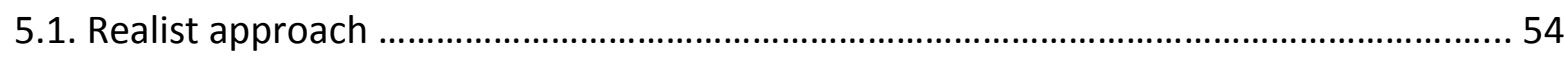

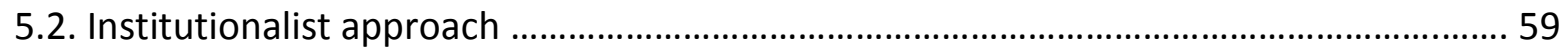

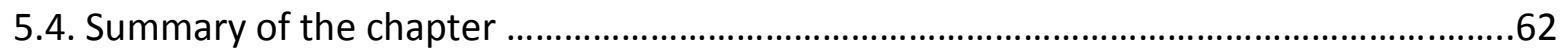

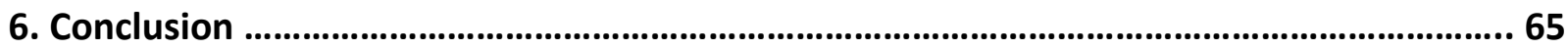

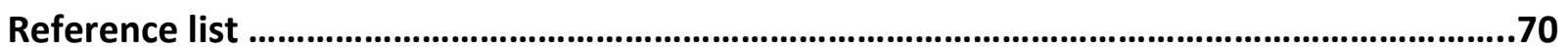




\section{Acknowledgements}

I would not be able to complete this Master thesis without accompany of the generous people whom I owe a deep gratitude. Here, I want to express my thankfulness to all those who supported and encouraged me during the course of this research project.

In particular, I want to thank Per Jansson for being an incredible program coordinator, for his patience through several delays and constructive criticism that helped me to develop myself as an independent researcher. My supervisor, Ronnie Hjorth, who has continuously supported and encouraged me during the whole process, has a valuable work in this project. I am also grateful to Peo Hansen who has read and commented on the initial draft of this master thesis and contributed useful comments and Jan Art Scholte whose lectures and seminars incited me to write my master thesis on this particular topic. I would like to thank Dzelila Piric who supported me through out the whole process and provided help with the linguistic issues of the project.

Finally, I am indebted to express my gratefulness to my family for their inexhaustible love, support and belief in me. Therefore, I dedicate it to them. 


\section{Acronyms}

\begin{tabular}{|c|c|}
\hline GCIM & Global Commission on International Migration \\
\hline GFMD & Global Forum on Migration and Development \\
\hline GMG & Global Migration Group \\
\hline ICMC & International Catholic Migration Commission \\
\hline ICPD & International Conference on Population and Development \\
\hline ILO & International Labor Organization \\
\hline IOM & International Organization for Migration \\
\hline HRW & Human Rights Watch \\
\hline MFA & Migrants Forum in Asia \\
\hline MRI & Migrants Rights International \\
\hline MWC & United Nations Convention on Migrants Rights \\
\hline UNCHR & UN High Commissioner on Human Rights \\
\hline UNDP & UN Development Program \\
\hline UNDESA & UN Department of Economic and Social Affairs \\
\hline UNFPA & UN Population Fond \\
\hline UNHCR & UN High Commissioner for Refugees \\
\hline WHO & World Health Organization \\
\hline WTO & World Trade Organization \\
\hline
\end{tabular}




\section{ABSTRACT}

The aim of this thesis is to analyze the recently formed global governance of migration, which has got an unprecedented trans-boundary nature due to the impacts of globalization in the post Cold War era. The novelty of this research is that it does not study the reasons or patterns of human movements, but it rather focuses on the politics governing this social phenomenon on the global level. To do so, first of all, the thesis classifies various global arrangements of international migration based on their structure, and later provides a critical assessment of their strengths and weaknesses. Second, the thesis examines the empirical viability of potential civil society contributions to the politics of international migration and argues that civil society engagement has so far been extremely limited and less productive in this policy area. Third, the thesis provides a comparison of the global migration governance to the issues, such as trade, health and climate change, which have got the same level of transboundary nature with highly institutionalized global arrangements. Finally, this project intends to explain the politics of international migration by applying normative arguments of two actororiented IR theories - Realism and Institutionalism - and provides an answer to the question of why the international migration is governed as it is today. It argues that Realism is the dominant $I R$ theory which best explains the empirical reality by highlighting the notions of security, sovereignty and national interests of rational nation-states, which have so far been hindering the establishment of a comprehensive international regime for the management of migration.

Considering the outcome of this project, a critical analysis of the global politics of international migration will increase our awareness of the significant shortcomings of the existing global migration governance, which in turn will help us to understand why this governance is neither effective nor satisfactory in comparison to other global policy areas. 


\section{CHAPTER ONE}

\section{INTRODUCTION}

\subsection{Research problem and research questions}

Migration is an inseparable social phenomenon of human being's life. It is a physical movement of human beings from one area to another for a short or long term, within or outside of state borders. There are various reasons behind migration. After a long analysis of reasons that make people migrate, sociologists came up with the "push-pull" model. This model differentiates between push factors that usually happen in a sending country and force people to leave their home, and pull factors that take place in a receiving country and attract people to new locations. ${ }^{1}$ While negative facts, such as economic disadvantages (unemployment, poverty), political or religious prosecution, and environmental effects of climate change, wars or natural calamity are included into push factors, positive facts, such as high level of social and economic life, freedom of political and religious thoughts and labour demand in capitalist markets should be considered as pull factors. Through the history of human life the content of migrants has been changing and developing, and today it includes refugee, asylum seeker, trafficked person, undocumented migrant, migrant worker and his/her family, and an international student. ${ }^{2}$

Today, we have to agree without any hesitation that international migration became a crucial part of our global life. Like trade, finance, climate change and environment issues, migration has got unprecedented global dimensions. Especially since the end of the cold war, migration has become a very influential factor in a relationship between governments because of its significant direct and indirect impacts on the economies, demographics, and daily life in countries of origin, transit and destination. According to the statistics of the United Nations

\footnotetext{
1 "Migration and Globalization" (2010), a project of the Levin Institute (The State University of New York), http://www.globalization101.org/uploads/File/Migration/migration2010.pdf

2 "Global Governance and Migration: Towards a Normative, Migratory Framework" by Holly Kirpatrick, http://www.guyanajournal.com/migrant.html
} 
Departments of Economic and Social Affairs, (UN DESA) the number of international migrants has grown from 155 million in 1990 to 214 million (about 3.1\% of the world total population) today (UNDESA, 2009). But it is not only about an ongoing increase in total volume of migrants. As Sara Kalm argues, "the movement of people has also expanded geographically so that all states and regions in the world are now affected at some point of the migratory chain, as senders, receivers and transit areas" (Kalm, 2008: p. 13).

In this project I will profoundly analyze different aspects of the global governance of migration which emerged at the beginning of the $21^{\text {st }}$ century and today, is in the process of development. Here the term "global governance" refers to a process of formulation and regulation of uniformed rules, standards and principles in a global arena by different actors. The Commission on Global Governance, which was established in 1992, made a standard definition of global governance stating that "Governance is the sum of many ways individuals and institutions, public and private, manage their common affairs. It is a continuing process through which conflicting or diverse interests may be accommodated and co-operative action taken. It includes formal institutions and regimes empowered to enforce compliance, as well as informal arrangements that people and institutions either have agreed to or perceive to be in their interest" (Commission on Global Governance 1995: p. 2). To explain it more, "By global governance, we mean the overarching system which regulates human affairs on a worldwide basis. [...] The mechanisms and rules of global governance are created by the actions and agreements of key actors in the global system" (O'Brien/Williams in Meyer, 2010: p.2).

If we look through the governance of migration until the beginning of the $21^{\text {st }}$ century, we will notice that due to its politically sensitive and strategic character states tried to follow independent domestic policies governing the movements of people but the results of these policies were often not in the best interest of the migrants or the states, and led to migration related problems on a global level. In the century of globalization, like environmental, trade and financial issues, gradually migration also gained global character and there was a need for a global framework for international migration.

The former Secretary General of the UN Kofi Annan stated in his reform proposal, "It is time take a more comprehensive look at the various dimensions of migrant issue, which now 
involves hundreds of millions of people" (United Nations, 2002: p. 10). Therefore, today we can see an ongoing shift towards setting up comprehensive and supranational standards and rules for migration under the framework of the global governance of migration. In addition to states, intergovernmental organizations, trans-governmental arrangements, NGOs, and different kinds of civil society groups participate in the global governance of migration. However, in contrast to other subject areas in international relations, migration is characterized by a comparatively low level of institutionalized international cooperation and states are still central actors in migration governance, and have so far been reluctant to create binding forms of cooperation at the global level (Kalm and Piper, 2010: 3). As a result, there is no any comprehensive international organization at the centre of global migration governance, such as the WTO for trade or the WHO for health issues.

Nevertheless, the absence of such an intergovernmental organization does not mean that there is no a global governance of migration. During the last decade an increasing number of international organizations and civil society groups became involved in different aspects of migration. However, there are two problems (empirical and academic) related to the global governance of migration which drew me into doing this research study. The empirical problem is that an existing global politics of international migration has a lot of shortcomings in terms of democracy, justice and efficiency. The academic problem of the issue is that most of the research studies on this topic pay too much attention to a state as a major actor of migration governance and almost mistakenly exclude analyzing the role and importance of other formal and/or informal actors actively involved in the process. As a result, it has not been possible so far to get the reasons of and solutions to the empirical problem of the subject issue. Therefore, the absence of academic studies until recently dealing with the empiric problem of the global governance of migration made me curious about this research problem. To say literally, this "negative" fact turned to be a "positive" inspiration for my research study. And finally, I have to confess that the theme of my research study is influenced by Jan Art Scholte's studies in "Global Governance" and "Civil Societies" and Sara Kalm's recent studies in the global migration governance. 
The above mentioned empiric reality (problem) of the research issue and my curiosity in this topic fostered me to come up with the following research questions.

- Where do the rules of the global governance of migration come from?

- What is the role of intergovernmental organizations in the global governance of migration?

- What are the contributions and shortcomings of civil society groups engaged in the global governance of migration?

- What can be learnt from the global governance of other global issue-areas, in terms of democracy, justice and efficiency?

\subsection{Aim of the study}

As I mentioned in the introduction, migration became a subject of international forums and discussions at a global level very recently, at the beginning of this millennium. Therefore, there have not been enough academic studies and researches on migration or any other issues related to migration concerning its global characteristics. To put it in a different way, there has been a little attention to the global governance of migration. Most of the academic studies on this topic have focused on internal dimensions of migration viewing a state as the only or major actor of the regulation of migration issues.

However, migration is today officially and explicitly acknowledged as a global phenomenon (rather than ignored or tacitly tolerated), as "here to stay" with all the implications for origin and destination countries as well as for the migrants themselves. (Kalm and Piper, 2010: p. 12-13). Today not only states, but also intergovernmental agencies, informal trans-governmental arrangements and plenty of different types of civil society groups are participants of the existing global governance of migration. Thereby, there is a need for a different academic approach to the studies of migration which can deal with different aspects of the global migration.

Keeping in my mind this insufficiency of academic studies within political science, I will endeavour to focus on the global/external dimensions of migration, rather than 
internal/domestic sides of it. To explain it more, this research is not studying the reasons or patterns of human movements, but rather the politics governing this social phenomenon at the global level. Thereby, the main (a direct) aim of this project is to explore the newly formed global governance of migration. By doing so, I hope, I will be able to contribute the following to the academic studies of migration:

- To contribute to the understanding of this newly emerging type (global) of the governance of migration;

-To scrutinize and classify the existing institutional types of the global governance of migration;

-To explore the engagement of civil society groups in the global governance of migration;

-And finally to find out the strengths and shortcomings of the global governance of migration from the perspectives of both intergovernmental institutions and civil society groups;

A secondary (an indirect) aim of this project is to draw the attention of the researches in the political science to the further studies of the global governance of migration. The more academic researches and studies are made on this topic, the more alternatives for a better global governance of migration can be drawn out.

Furthermore, I will compare the global governance of migration to the global governance of other issue areas which has got global dimensions like migration, such as finance, trade, environment, climate change and health. In such comparison, I will especially focus on the engagement of different civil society groups and their insights to the global governance of the mentioned issue areas. Through this comparison I will be able to find out the strengths and weaknesses of the global governance of migration.

As a whole, this project should be considered as a critical analysis of the existing politics of the global governance of migration, and as an argumentative proposal on more democratic, fairer and much more efficient global governance of migration based on the respect of human rights which can be politically feasible and mutually beneficial for its participant actors. 


\subsection{Theoretical considerations}

It is an incontestable fact that the theories of International Relations studies equip academic researchers with significant tools to explore and understand different aspects of the empirical issues. The importance of these tools is that they offer us different alternatives on one specific issue which are useful for analytical comparison among them and for further research studies for better understanding of a specific research problem.

Thereby, I want to explore the research problem from the different alternatives of IR theories related to the concerned issue. Here my main aim with using the different theoretical approaches is to explain how the term "global governance" is understood in the context of migration and how different understandings of one specific issue can offer different assumptions about the future development of the global migration governance. To be more specific, even though each IR theory at least has something to say about the concerned issue, I will explore my research problem from the view points of two major IR theories: Realism and Institutionalism. Why just these two theories? The answer is that the global governance of migration resembles two controversial sides of the same coin. On the one hand there is an ongoing shift towards setting up comprehensive and supranational standards and rules for migration under the framework of the global governance of migration, on the other hand, as a major actor of an ongoing process states are still reluctant to loose their full sovereignty to decide who, when and under which conditions can enter, stay and leave their territory and thus they avoid from agreeing on strongly binding global migration norms and rules. While Institutionalism is very strong to explain the process going on the first side of the coin and predict future development of global migration governance, Realism can say too much about the second side of the coin rather than the institutionalism and it can offer totally different assumptions about the future development of the issue.

According to the general approach of realism on a globalization and global governance, (Scholte, 2010, lecture notes) global migration governance is an outcome of a power struggle among states and designed by powerful states to control the international flow of people from one area to another. "Governments continue to be the only institutions with the legitimacy to employ force to achieve social objectives and to enforce agreements" (Gilpin in Held and 
McGrew, 2002: 240). Thus, the effectiveness and the future development of the global governance of migration will depend on the interests of these decisive states. Making a quotation from Kenneth Waltz "States have to ensure their survival themselves, and states that do not orient their policy rationally according to this self imperative will inevitably perish" (stated in Rittberger, Zangl and Staisch, 2006: p. 15). To say in a different way, realism views the global governance of migration as a state-centric process.

Supporters of institutionalism agree with the realist scholars on the importance of states in the global governance, however they do not exaggerate this importance and instead pay attention to non-state actors engaged in global governance of migration. In contrast to realism, they argue that as a result of an ongoing globalization an increasing interdependence among states have pushed states and non-state actors to create and develop a global governance of migration. To add more, for institutionalism, the emergence of the global governance of migration at the beginning of the $21^{\text {st }}$ century was a result of the need to facilitate the regulation of global dimensions of the increasing migration. When a problem arises as a consequence of an increasingly close interdependent relationship across state borders, some form of organization automatically emerges in order to tackle that problem (Rittberger, Zangl and Staisch, 2006: p. 16-17). Here we can imply that without global governance the regulation of migration would be impossible.

Moreover, institutionalism would argue that the effectiveness and the future development of the global migration governance depends on the convergence of interests obtained in the considering issue, rather than on behavior and decisions of powerful states as realism argues. For institutionalism the existing intergovernmental organizations, inter-agency and trans-governmental institutions under the framework of global governance, constitute democracy and justice to this issue area. However, in comparison to the global governance of other issue areas, as many scholars argue, these institutions have considerable deficits in terms of democracy, justice and efficiency which will be in the limelight of my research study in the following chapters. My answers to the research questions will mainly be explored in the context of these two theories, however depending on the data and information attained during the 
research process, I may include other theoretical approaches if it helps for a better understanding of the concerned issue.

\subsection{Research strategy and methodology}

A successful accomplishment of an academic research concerning its result and contribution to a study field depends on the methodology and the research design used by an author. Chosing appropriate research methods requires us to look at the aim of the study. In my project the main aim of the research study is to explore the global governance of migration and to find out to which extent this governance is fair and effective. This academic purpose makes it necessary to investigate comprehensive norms and rules established under the framework of global migration governance and their impact on different aspects of international migration and migrants. To do so, I will need to combine qualitative and quantitative methods in the study of this specific issue, which means the research problem will be analyzed both from interpretivist and positivist approaches of social science.

By using quantitative methods under a positivist approach I will be able to get an access

to the official statistics of global migration and analyze these gathered data outside of a subjective meaning. According to the supporters of positivism social phenomenon exists as an objective entity outside of the mind of the observer and the task of the researcher is to describe and analyze this objective reality in a neutral way (Della Porta \& Keating, 2008: p. 23). This method will lead me to a neutral position and hopefully reliable results concerning my main study aim in this research. I am planing to scrutinize data of International Labor Organization (statistics about migrant workers and their rights), UN High Commissioner on Refugee (statistics about refugees and asylum seekers), Human Rights Watch (statistics and reports on human rights of migrants) and some important statistics of NGOs and other civil society groups. After analyzing this data I will copmare it to each other and previous ones to see if there is any development in the global governance of migration.

However, in order to critically analyze uniformed rules, norms and agreements of the global governance of migration I will need to input a subjective meaning on the study issue and apply qualitative methods under the interpretivist approach. According to Della Porta and 
Keating, "In the most radical versions of this approach, reality does not exist beyond the (relative and partial) images the various actors have of it. Knowing the reality is therefore impossible and scholars should focus on the meaning through empathetic knowledge" (2008: p. 25).

To be more specific, I will take main international conventions, agreements, and declarations about different issues of migration under the framework of a global governance (primary research sources) and endeavor to contextually analyze them. Reports of issue related intergovernmental organizations, different civil society groups and international forums and groups of migration, and speaches of some officials will be included into this interpretivist analysis. Secondary research sources, such as outcomes of previously conducted researches, articles and scientific publications will be analyzed in this thesis as well. To add more, the data gathered by quantitative methods will be analyzed together with the theoretical background framed in this research study.

Taking into account the limited availability of reliable data and information, I will try to collect it from multiple sources which will make it possible for me to compare, check and evaluate different sources against each other.

I am planing to arrange my research study in two phases concerning research methods. In the first phase I will explore the existing global governance of migration by using quantitative methods. In the second phase I will analyze the level of effectiveness of the global governance of migration by using qualitative methods.

\subsection{Study outline and expected outcomes}

This study falls into six chapters. Chapter one has already introduced the research problem, questions, methodology and theoretical framework of the study. Each of the following chapters starts with a descriptive and comprehensive picture and later focuses on a critical analysis of the introduced information.

Chapter two, apart from being mainly a background chapter, classifies newly emerging types of the global governance of migration and explains the strengths and weaknesses of the existing politics of international migration. 
Chapter three introduces civil society actors involved in the global governance of migration and measures their engagement level in a policy making process, as well as their potential contributions and shortcomings to this policy area.

Chapter four presents a comparison of the global governance of migration to those of climate change, trade and health. It points out how in a different way global migration is governed in contrast to these policy areas and discusses the main findings that should be learnt from this comparison.

Chapter five profoundly discusses the implications of two major theoretical approaches presented in the Introduction chapter and points out the strengths and weaknesses of each theoretical view. Finally, chapter six summarizes and discusses the main findings of the study.

Considering the outcome of this project, first of all, this academic study will help us to develop our understanding about the global politics of International migration. We will hopefully be informed where the uniform rules and norms of the global governance of migration come from and what the impacts of these global rules and norms are on the international flow of migrants.

Secondly, critical analysis of the global politics of international migration will increase our awareness of significant shortcomings of the existing global governance of migration which in turn will help us to understand why this governance is not either effective or satisfactory in comparison to other global issues areas.

Thirdly, I will come up with an argumentative proposal telling us what is needed to be learnt from the other issue areas and what should be done in order to make the global governance of migration more democratic, more just and much more efficient which can be politically feasible and mutually beneficial for its all participants.

Finally, this research study is expected to draw the attention of researchers in this subject field to further studies of the global governance of migration. The more academic researches and studies are made on this topic, the more alternatives for a better global governance of migration can be drawn out. 


\section{EXISTING TYPES OF THE GLOBAL GOVERNANCE OF MIGRATION}

The very nature of transnational migration demands international cooperation and shared responsibility. Yet the reality is that most states have been unwilling to commit fully to the principle of international cooperation in the area of international migration. (Global Commission on International Migration, 2005: p. 66)

Before moving into the analysis of the international actors of the global migration governance, there is a need to point out the distinction between the "international governance" and the "global governance". This distinction will help us to understand why the actors which will be mentioned and analyzed in the rest of this chapter are considered as the participants of the global migration governance. Here, making a quotation from Rittberger, "the international governance is the output of a non-hierarchical network of interlocking international (mostly, but not exclusively, governmental) institutions which regulate the behavior of states and other international actors in different issue areas of world politics" (2000: p. 198; 2001: p. 2). However, "the global governance is the output of non-hierarchical network of international and transnational institutions" in which "not only IGOS and international regimes, but also transnational regimes are regulating actor's behavior" (Rittberger, 2001: p.2). This means that in contrast to the international governance, there is an increased involvement of non-state actors in the norm and rule formulation process in the global governance. One more point to be stressed for the clarity of the term, we should not assume the global governance as a global government; it is not a single top-down world order. It is rather the "collection of governance related activities, rules, and mechanisms, formal and informal, existing at a variety of levels in the world today" (Karns and Mignst, 2004: p. 4).

As I have already mentioned in the Introduction chapter, the absence of a single comprehensive intergovernmental organization in global migration, such as the World Trade Organization in trade or the WHO in health, does not imply that there is no global cooperation and governance in international migration. As Sara Kalm states, "the past decade has also seen 
an increasing number of international organizations becoming involved in migration in its various aspects, a more conscious organization on part of non-governmental organizations in order to influence policy-making, and the emergence of independent policy initiatives with the ambition to address migration comprehensively" (2008: p. 36).

Since some scholars have already discussed different international actors involved in the framework of the recently emerging global governance of migration, (Newland 2005, Green and Thouez 2005, Tanner 2006, Channac 2007, Kalm 2008) this chapter should be partly considered as a background chapter which presents a comprehensive review of the existing global migration governance. Moreover, this chapter reviews the types of the global migration governance based on the structure of the cooperation. I have classified two major types of global migration governance: 1) Formal - Institutional Governance and 2) Informal Governance.

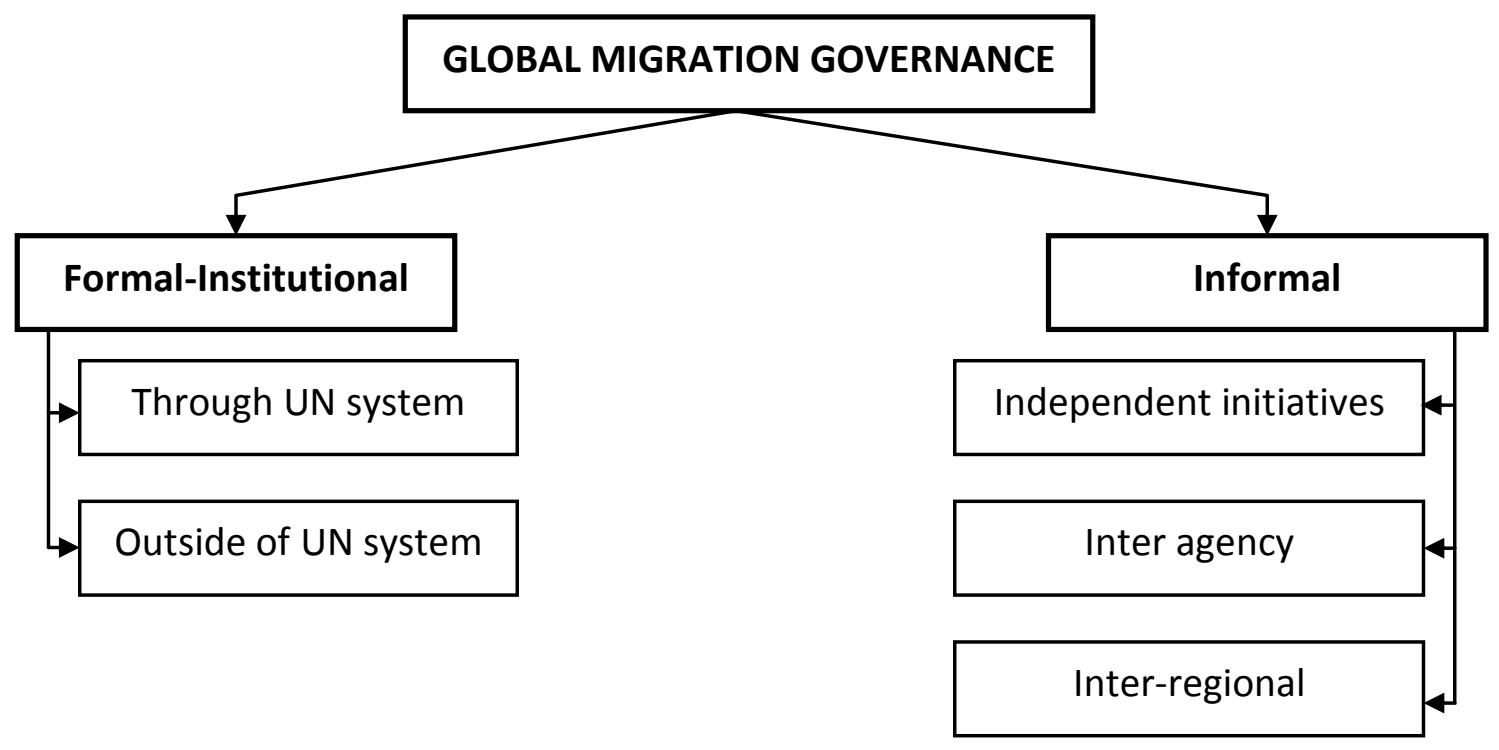

By mapping out such a review including this classification, the chapter illustrates who, how, when and where participates in the formulation of universal norms, rules and principles of the global governance of migration. Moreover, it demonstrates the strengths and weaknessess of each governance type.

Finally, the outcome of this chapter will be used in Chapter five for the theoretical approaches which will try to explain (mostly, assume) why the global migration is governed as it is. 


\subsection{Formal - Institutional Governance}

\section{A) Within the United Nations System}

In addition to being one of the key actors in global governance, Intergovernmental organizations have always been considered as the major arena where a multilateral cooperation among different policy actors takes place. Therefore, one can assume this general approach about global migration governance as well. However, in spite of being one of the most trans-boundary and complex policy areas, the degree of institutionalized intergovernmental cooperation which exists within the framework of global migration governance is considerably limited and weak in comparison to other trans-boundary issue areas, such as climate change, finance, international trade, communicable disease and etc., where states have arranged a coherent institutionalized cooperation either through a single intergovernmental organization or the United Nations (UN) system. But there is no either UN migration organization or any international migration regime, and states still have a high degree of sovereignty in determining their own migration policies (Bhagwati 2004; Ghosh 2005; Betts 2008, 2011).

However, there are two exceptions to be pointed out. The major exception is in refugee and asylum protection, which has a formal regime and is governed through the UN system, by the UN High Commissioner for Refugees (UNHCR). This regime is based upon the 1951 UN Convention on the Status of refugees and 1967 Protocol. $^{3}$ In total, 147 states are parties to one or both of these instruments (UNHCR 2011: p.1). The international cooperation under this coherent institutional refugee regime is generally understood regarding responsibility for assisting and protecting refugees, asylum seekers and internally displaced persons (Martin 2005, Kalm 2008). Currently, of the nearly 20 million people under the concern of the UNHCR, 12 million are refugees, over 6 million are internally displaced people, one million are asylum seekers, and half a million are recently returned refugees (Newland, 2005: p. 11). Here, the refugee and asylum protection is one out of many other policy sectors of international migration. Other policy sectors and issues related to international migration, for example, labor

\footnotetext{
${ }^{3}$ For a detailed information about the Convention and Protocol, see the official website: http://www.unhcr.org/cgi-bin/texis/vtx/home
} 
migration, irregular migration, environmental migration, human trafficking and smuggling are in the policy agendas of the different UN specialized agencies, such as UN Department on Social and Economic Affairs (UNDESA), United Nations Population Fund (UNFPA) and UN High Commissioner for Human Rights (UNHCHR).

Through its Population Division, the UNDESA holds the secretariat of the Commission on Population and Development and monitors the implementation of the Action Programme of the 1994 Cairo International Conference on Population and Development. ${ }^{4}$ The UNFPA, which is the world's largest multilateral source of population assistance, upholds the agenda of the International Conference on Population and Development (ICPD) in the area of migration by promoting policy dialogue, organizing meetings and assisting governments in collection of migration statistics. It also finances technical trainings to develop policy and legal frameworks for combating migration related problems, with particular concern of women migrants' rights and human trafficking. The UNHCHR, taking the 1990 UN International Convention on the Protection of the Rights of All Migrant Workers and Members of their Families ${ }^{5}$ as a base, is responsible "to examine ways and means to overcame the obstacles existing to the full and effective protection of the human rights of this vulnerable group, including obstacles and difficulties for the return of migrants who are non-documented or in an irregular situation" (Newland 2005: p. 12).

To make a general characteristic of these three UN specialized agencies, none of them has a formal institutional regime in contrast to the UNHCR, and their role in global migration governance should be considered as providing services and monitoring policy implementation. Concerning the UNHCR, the latest disasters in the Mediterranean Sea, which have taken away lives of thousands of African migrants trying to flee from Libya to Southern European shores to get an asylum or refugee status, stress out shortcomings of this institution as well. Just to give a very latest example, according to the UK newspaper Guardian, 61 migrants out of 72 passengers fleeing to Italian island of Lampedusa from Libyan capital Tripoli have been left to die of hunger and thirst in their small boat in an open sea even though they have been begging

\footnotetext{
${ }^{4}$ http://www.un.org/en/development/desa/about/divisions.shtml

5 For a detailed text of the convention see: http://www2.ohchr.org/english/law/pdf/cmw.pdf
} 
for the rescue by the NATO maritime unit who is responsible for the safety of life at sea with regard to the international maritime law (Guardian, 8 May, 2011).

Another intergovernmental organization, which operates within the framework of global migration governance inside the UN system, is the International Labour Organization (ILO). According to its constitution, with its hybrid (tripartite) organizational structure, where state representatives, employers' associations and workers (labour union confederations) equally participate, the ILO is protecting the interests of migrant workers employed in countries other than their own. Its International Migration Programme (MIGRANT), responsible for labour migration in the ILO, aims to protect the rights of migrant workers, as well as to develop the understanding and knowledge base of migration (Kalm, 2008). In terms of protecting the interests and rights of migrant workers, the ILO is operating under the two main conventions: 1949 the ILO Migration for Employment Convention, ${ }^{6}$ (no. 97) and 1975 the ILO Migrant Workers Convention ${ }^{7}$ (no. 143). However, only 42 and 18 member states, respectively, have ratified these conventions. Taking into account that the ILO conventions are legally binding only in case they are ratified, the above mentioned fact about the amount of ratified states points out that most of its member states are not willing to bind themselves to its provisions.

To make a general comment on the ILO's activities in the global migration governance, it has not been active enough in the debates on international migration until recently (Newland, 2005: p. 10). After rejoining the debates at the beginning of the $21^{\text {st }}$ century, it established a "World Commission on the Social Dimensions of Globalization" in 2002. In 2004, the Commission published its report named "A fair Globalization: Creating Opportunities for All" (ILO, 2004:a) and adopted the "Resolution Concerning a Fair Deal for Migrant Workers in a Global Economy" (ILO, 2004:b). Today, as a standard setting body, the ILO is focused on setting out non-binding principles and guidelines to develop the implementation of its labour migration policies.

\footnotetext{
${ }^{6}$ For a detailed text of the Convention see: $h$ ttp://www.ilo.org/ilolex/cgi-lex/convde.pl?query=C097

${ }^{7}$ For a detailed text of the Convention see: http://www.ilo.org/ilolex/cgi-lex/convde.pl?query=C143
} 


\section{B) Outside of the United Nations System}

Another exception, which I mentioned above, is about the International Organization for Migration (IOM), the leading and only intergovernmental organization which deals with international migration outside of the UN system. Established in 1951 as the Provisional Intergovernmental Committee for the Migrants from Europe, the IOM turned from an operational and logistic agency to the leading international agency in 1989. Today it has 132 member states and 97 observers, 80 of which are global and regional IGOs and NGOs. ${ }^{8}$ According to the provisions of its Constitution, ${ }^{9}$ the IOM has set up the following purposes and functions:

- To make arrangement for the organized transfer of migrants to countries offering opportunities for orderly migration;

- To concern itself with the organized transfer of refugees, displaced persons and other individuals in need of international migration services for whom arrangements may be made between the organization and the states concerned, including those states undertaking to receive them;

- To provide, at the request of and in agreement with the states concerned, migration services, such as recruitment, selection, medical screening and so forth;

- To provide similar services as requested by states, or in co-operation with other interested international organizations, for voluntary return migration, including voluntary repatriation;

- To provide a forum to states as well as international and other organizations for the exchange of views and experiences.

In general the IOM has identified four priority areas for international migration management: migration and development; facilitating migration; regulating migration, and forced migration. In addition to carrying out these purposes, in 2001, the IOM initiated the

\footnotetext{
${ }^{8}$ For a more detailed information see the official website: http://iom.int/jahia/isp/index.jsp

${ }^{9}$ See:

http://www.iom.int/jahia/webdav/site/myjahiasite/shared/shared/mainsite/about iom/iom constitution eng bo oklet.pdf
} 
"International Dialogue on Migration", which is an informal consultation mechanism, to provide a global forum for government representatives and non-state actors on a regular basis.

To draw out a general characteristic of the IOM, in spite of being the only intergovernmental organization, which deals with all aspects of migration, it is not working under any institutional migration regimes. In contrast to the UNHCR, it does not have any clear mandate or normative basis for its work. As it is obvious from its constitution, the IOM exists mainly as "a service-provider to states, providing advice on the best practice and running migration related projects in areas such as migration management, facilitating migration, migrant health, and the movement of people in post-conflict settings" (Betts, 2008: p.9).

\subsection{Informal Governance}

\section{A) Independent Initiatives}

In the absence of a coherent and formal institutional framework, both inside and outside of the UN system, the growing trans-boundary nature of international migration highlighted the need for a greater multilateral cooperation in the area of global migration governance. Thus, during the past decade, the various states and global actors, understanding the difficulty of managing multifaceted aspects of this complex issue-area, have been calling for various global forums and commissions in the informal base, where they have tried to discuss the politics of international migration governance and to agree on politically feasible comprehensive norms and principles. Hereby, the first step was taken in 1994, at the United Nations International Conference on Population and Development in Cairo. The chapter $\mathrm{X}$ of the Action Programme, which covered international migration, offered a series of policy orientations covering, "inter alia, the rights and obligations of migrants, the development of orderly migration programs, the prevention of trafficking in migrants, the reduction of unwanted migration, the promotion of the development potential of migration and the need for cooperation between countries in successfully managing migration" (Klein Solomon, 2005: p.2). However, the unwillingness of states, mostly migrant receiving industrialized countries, which preferred to retain their sovereign autonomy on migration management, enabled debates on 
international migration until the beginning of the new millennium. The following four independent initiatives on international migration have been launched during the last ten years.

\section{Bern Initiative}

Launched in 2001, by the Swiss government (later, with the Government of Sweden), the so-called independent "Berne initiative" is a state-owned informal consultation mechanism outside of the traditional institutional structures, which is a respond to the need of an interstate cooperation and dialogue on international migration (Klein Solomon, 2005, Channac, 2007, Betts, 2008). Having a secretariat under the IOM, the Berne Initiative was aiming to bring together the representatives of governments from all over the world, IGOs and civil society actors to enable them to share their experiences, interests and offers on international migration management and to develop a common approach to global migration governance. To achieve these goals, after a series of interstate consultations, the Berne Initiative set up its nonbinding "International Agenda for Migration Management" in 2004, which is considered its most important outcome. ${ }^{10}$ Various migration related issues, for example, migration and development, labour migration, human rights of migrants, irregular migration, trafficking and migrant smuggling and so forth are included to its agenda. As a continuation of this agenda, four regional consultations, one of each for Africa, Europe and Central Asia, Asia and Pacific, and Americas and Caribbean have been held to find out the common interest of states to the above mentioned issues and share the best practices on international migration management.

To valuate the contributions of the Berne initiative, it should be stated that it has played an invaluable role in terms of uncovering and reporting the existing problems of international migration, and offering the best practices to states to manage these problems. Regarding a civil society inclusion to the consultations in addition to states and IGOs, we can consider the Berne Initiative successful. As Channac states, "the Initiative of Berne is dominated by states, and the participation and role of non governmental actors is more than marginal" (2007: p. 15). However, its contributions have not been able to move forward from establishing "a common view" on international migration. Its non-binding agenda and lucking legal institutional

\footnotetext{
${ }^{10}$ See: Bern Initiative Consultations (2-3 July 2003, Berne), Final Report: “An International Agenda for Miration Management", p.3.
} 
framework are not able to push states to sacrifice some piece of their sovereignty in order to establish coherent comprehensive norms and rules based on the human rights of migrants.

\section{Global Commission on International Migration}

Another independent initiative for a multilateral dialogue and cooperation on international migration was the Global Commission on Migration (GCIM), launched in December 2003, by the UN Secretary General. The GCIM "is independent and was given a mandate to provide the framework for the formulation of a coherent, comprehensive and global response to the issue of international migration". ${ }^{11}$ Hereby, in 2005, the GCIM presented its final report, called "Migration in an interconnected world: New directions for action" with a series of recommendations and offers to the UN Secretary General. Providing the general overview of international migrations' nature and scope, in its report, the Commission presents the growing challenges of international migration and highlights the need for a coherent and comprehensive institutional framework on a global level:

"The Commission proposes to the UN Secretary-General the immediate establishment of a high-level interinstitutional group to define the functions and modalities of, and pave the way for, an Inter-agency Global migration Facility. This facility should ensure a more coherent and effective institutional response to the opportunities and challenges presented by international migration" (GCIM, October 2005, p. 82).

The Commission also emphasizes the need for the coherence of migration policies at national level and their consistency with international treaty laws, with particular focus on human rights laws for more effective global migration governance:

"Coherence begins at home, and if states cannot define the clear objectives for national migration policies, it should not come as a surprise that overlaps and contradictions sometimes occur at the multilateral and institutional level......All states should establish coherent national migration policies that are based on agreed objectives, take account of related policy issues and are consistent with international treaty law, including human rights law. Governance at the national level should be effectively coordinated among all concerned ministries and should also involve consultation with non-state actors" (GCIM, October 2005, p. 76).

To comment on the Commissions' role in global migration governance, everyone should agree that it did much by putting the issue at the centre of the international agenda and by emphasizing attention to the establishment on an institutional framework for efficient governance on a global level. However, like the Berne Initiative, the GCIM could not go beyond

\footnotetext{
${ }^{11}$ See the official website: http://www.gcim.org
} 
playing the role of collecting information and offering non-binding recommendations to states. Regarding its view on civil society inclusion in global migration governance, even though the GCIM stresses the potential role and place of non governmental actors in multilateral cooperation, it still gives a central role to states and views their sovereignty as a condition for effective governance of international migration.

\section{The High Level Dialogue on Migration and Development}

Concerning the complexity of the issue and the need for the continuation of international cooperation at all levels of international migration, in 2004, the General Assembly of the UN decided to set up the High Level Dialogue on Migration and Development in 2006. The aim of the high level dialogue was "to discuss the multidimensional aspects of international migration and development in order to identify appropriate ways and means to maximize its development benefits and minimize its negative impacts" (United Nations, 2004a: p.4) To achieve its goal the General Assembly held this dialogue, which consisted of four plenary meetings (high level officials of 127 member states), four interactive round tables and one-day informal hearings with the representatives of non-state actors, in September 2006, New-York. ${ }^{12}$

To summarize the general outcome of this high level dialogue, affirming the growing global character of international migration, all participants stressed that if governed by the right set of policies and rules, which respect the fundamental rights and freedom of all migrants, this social phenomenon would be a positive source for the development both in the sending and hosting countries, rather than a negative factor. Moreover, nearly all of the participating states expressed their interest to continue international cooperation in this issue area in a global forum and welcomed the Secretary General's proposal about the establishment of "The Global Forum on International Migration and Development". However, there was a disagreement about the structure and the organizational details of such a global forum. While countries of origin, mostly developing countries, offered a formal structure, which would produce legally binding norms for global migration governance, countries of destination, mostly developed

\footnotetext{
${ }^{12}$ For the detailed summaries of each roundtables and informal hearing see: http://www.un.org/esa/population/migration/hld/
} 
countries, opposed to this idea by offering an informal structure with non-binding decisions. As a result of negotiation, in his concluding address of the high level dialogue, Kofi Annan stated:

"Clearly, there is no consensus on making international migration the subject of formal, norm-setting negotiations. There is little appetite for any norm-setting intergovernmental commission on migration. But, as I understand the thinking of the countries that back it, the forum would be opposite of that. It would be informal, voluntary, consultative. Above all, would not make binding decisions" (United Nations, 2006a).

To make a critical comment on its outcome, like previous independent initiatives, the high level dialogue has not been able to do more in terms of establishing the formal and coherent institutional framework, rather than just mapping out the existing problems of international migration and suggesting the means of managing global migration through informal and voluntary cooperation.

\section{Global Forum on International Migration and Development}

As it is indicated in the above mentioned quotation by the Secretary General, The Global Forum on International Migration and Development (GFMD) was established as a governmentled voluntary and informal global arena, where participants can exchange information, interests and practices and develop practical policies on international migration governance. It is intended "to add value to the current debate on international migration and development by fostering international cooperation, enhancing inter-state dialogue, discuss and promote new policy ideas in the field of migration and structure the international priorities and agenda on migration and development". ${ }^{13}$ To achieve these intended objectives, the first GFMD meeting was organized and hosted by the government of Belgium, in 2007. The following three annual meetings have taken place in Manila, Athens and Mexico and the next one will take place in Switzerland. Those meetings have been organized outside of the UN system, which has been considered as its main shortage by many civil society actors. According to Kalm, non-state actors felt that "if global discussions on migration were re-incorporated into the UN system, this would ensure that UN human rights instruments would be integrated into the evolving global migration governance" (2008: p. 56).

\footnotetext{
${ }^{13}$ See the link: $\underline{\text { http://gfmd-fmmd.org/en/foruminfo/objectives }}$
} 
To evaluate the work done by GFMD, the recommendations and proposals of each annual governmental meeting of the GFMD during 2007-2010 have been addressed to its participating states, which could have voluntarily implemented or disregarded them. According to the records of GFMD, more than $50 \%$ of its 32 proposals for action from Brussels and Manila had been implemented by 2010 (GFMD, 2010). In parallel to government meetings, civil society days have been organized to let non-state actors engage in policy discussions. Whether civil society actors have been able to input their positions during the discussions, and shape the policies, or not will be profoundly discussed in the next chapter.

\section{B) Inter agency arrangements}

As it is apparently obvious from previous sections, there have been organizational overlaps in the international cooperation and debate on global migration governance. Different institutions, both within the UN system and outside of it, and various independent initiatives have been dealing with different aspects of international migration at the same time, but separately, and they have not been able to promote binding normative decisions, with the exception of refugee and asylum protection under the UNHCR. To give a clear example, the work of GCIM was running parallel to the preparations of the High Level Dialogue on Migration and Development as a separate arrangement, even though they were dealing with the same problems within the same informal and voluntary structure. According to Matsas, this made the global migration governance appear "fragmented and incomplete" (2008: p. 3). Thus, there was a need for inter agency arrangements, which could bring together the heads of institutions and free initiatives at regular meetings to make a constructive coordination between their policies for more productive cooperation and an outcome in international migration governance.

\section{Global Migration Group}

Established in 2006 by the UN Secretary General, the Global Migration Group (GMG) was a response to the recommendation of the GCIM, which proposed the establishment of a high level inter-institutional group of migration related agencies. It was built up on an existing inter-agency group called Geneva Migration Group, which was created in 2003 and had a 
relatively limited membership. ${ }^{14}$ The GMG consists of 14 participant agencies which are the followings: ILO, IOM, UNHCR, UNHCHR, UNFPA, UNDESA, UNISEF, UNESCO, UNDP (UN Development Programme), UNITAR (UN Institution for Training and Research), UNODC (UN Office on Drugs and Crime), UNCTAD (UN Conference on Trade and Development), World Bank and UN Regional Commission. ${ }^{15}$ By bringing together the heads of above mentioned agencies involved in migration related activities at the executive level, the GMG is intended to produce better governance for international migration, which would fully respect the human rights and labour rights of international migrants and provide a coherent framework and strong leadership to improve the overall effectiveness of global cooperation. According to its Terms of Reference $^{16}$, some of the key priorities of the GMG are the following:

- Exchange information and expertise to improve understanding, inter-agency cooperation and collaboration;

- Establish a comprehensive and coherent approach in the overall institutional response to international migration;

- Identify critical issues, opportunities, challenges, weaknesses, gaps and best practices in relation to international migration and its interrelations with development.

These key priorities once again prove that the GMG is an outcome of the necessity to overcome the organizational overlaps in global cooperation on international migration, and its valuable role in coordinating the fragmented and incomplete policies of global migration governance should not be denied.

\section{International Migration Policy Programme}

Established in 1998, the International Migration Policy Programme (IMP) is the first inter-agency set of actors involved in a global migration debate. Like the GMG, the IMP also brings together the heads of migration related agencies to coordinate their separate activities

\footnotetext{
${ }^{14}$ See the official website: http://www.globalmigrationgroup.org/what is gmg.htm

${ }^{15}$ For a detailed information see the link: http://www.globalmigrationgroup.org/index.html

${ }^{16}$ See the link: http://www.globalmigrationgroup.org/pdf/Final\%20GMG\%20Terms\%20of\%20Reference_prioritized.pdf
} 
under one coherent policy programme. However, in contrast to the GMG, it focuses on the coordination of national and regional migration policies, rather than global. But it is not to say that the IMP does not have impact on the international debate of global migration. Since it is a policy coordination area, where the representatives of migration related agencies, senior officials of governments and expert groups from different regions come together to discuss and exchange useful information and best practices on international migration, then the IMP is indirectly involved in the global debate on international migration. As Channac states, "It aims at developing the capacities of the national governments so that the inter-state dialogue and the multilateral cooperation should be more effective and efficient at the regional level but also at the global level" (2007: p. 8). This is to say that the IMP's main aim is to develop the informal structures for regional and global dialogues between states and to contribute coherence to the global migration governance. For this purpose, the IMP had organized 16 regional meetings nearly in all regions of the world by $2004 .{ }^{17}$ The inter-regional governance of international migration, which will be discussed in following section, should be considered as an outcome of the IMP.

\section{C) Inter-regional cooperation}

International cooperation and debates on global migration governance do not only take place at the global level, but also at the regional and inter-regional level. In general, this type of cooperation on international migration is identified as Regional Consultation Processes (RCPS). Making a quotation from 2007 Working Paper of GFMD, "RCPs are state-led informal groups made up of representatives of states in a given region, or like-minded states in one or more regions with common migration interests. Participants in RCPs come together in pursuit of coordination and in some instances coherence on migration issues through informal and nonbinding dialogue and information exchange" (2007: p. 2). The advantage of the inter-regional cooperation on international migration is that it lets countries of origins, destination and transit from neighbouring regions exchange information and experience and seek a common approach

\footnotetext{
${ }^{17}$ For a detailed information see the link: http://www.ilo.org/dyn/migpractice/migmain.showPractice?p_lang=en\&p_practice id=6
} 
to migration related issue. To have a general picture of RCPs, it is necessary to provide some illustrative examples and bring to light the recent RCPs that emerged on an inter-regional basis.

One of the latest examples to inter-regional consultation is the so called "Abu Dhabi Dialogue" on labour migration that brought together 11 migrant sending countries of Asia (Colombo Process ${ }^{18}$ ) together with 9 migrant receiving countries, 7 of which were from the Gulf region and 2 from $A_{s i a}{ }^{19}$ at the ministerial level. The outcome of this ministerial-level gathering is the Abu Dhabi Declaration, in which participant states agreed to launch a collaborative approach to address temporary labour mobility and maximize their benefits for development (GFMD, 2008).

The best example of inter-regional consultations is the EU-Africa dialogue on migration, which includes the " $5+5$ " dialogue on migration between west-north (France, Italy, Malta, Spain and Portugal) and west-south Mediterranean states (Libya, Morocco, Mauritania, Algeria and Tunisia); 2006 Rabat and Tripoli Euro-Africa Ministerial Conference on migration and Development; and 2007 Lisbon EU-Africa Summit, all of which resulted in EU-Africa Partnership Declarations.

The so called ASEM dialogue, (Asia-Europe meeting) which brings together the European Commission, EU countries and certain Asian states ${ }^{20}$; the Ibero-American dialogue on migration between Latin American migrant sending countries and Spain, Portugal Andorra; the Puebla Process which is intended to develop cooperation on migration between NAFTA and Central American countries; and the EU-LAC (Europe/Latin America and Caribbean) Summit are other recent examples to inter-regional cooperation on migration. ${ }^{21}$ The group of examples provided here differ from each other regarding their major policy concerns. For example, while the EU-

\footnotetext{
${ }^{18}$ The Colombo Process is formally known as the Ministerial Consultations on Overseas Employment and Contractual Labour for Countries of Origin in Asia. Its members are Afghanistan, Bangladesh, China, India, Indonesia, Nepal, Pakistan, Philippines, Vietnam, Thailand, and Sri Lanka.

${ }^{19}$ These were the six Gulf Cooperation Council (GCC) States, Yemen and two additional Asian countries of destination, namely Malaysia and Singapore

${ }^{20}$ Brunei, China, Cambodia, Indonesia, Japan, South Korea, Malaysia, Myanmar, Laos, the Philippines, Singapore, Thailand, and Vietnam as well as India, Mongolia, Pakistan and the ASEAN Secretariat upon their completion of the necessary procedures.

${ }^{21}$ For a detailed list of RCPs and their participants see the link: http://iom.int/jahia/webdav/site/myiahiasite/shared/shared/mainsite/microsites/rcps/matrix overview major rc ps apr09.pdf
} 
Africa dialogue is mainly focused on discussions of irregular migration and capacity building for African states to overcame migration related problems, others are mainly intended to deal with labour migration, work conditions and human rights of migrant workers.

The general feature of the above mentioned inter-regional cooperation on migration is that like other types of international cooperation, they are also based on an informal and voluntary structure, which provides non-binding and non-normative decisions, declarations, and plans of actions or guidelines. As Klekowski von Koppenfels argues, "states under no obligation to belong to a regional consultative process nor do they suffer sanctions from nonparticipation" (2001: p. 24). Moreover, since their objectives are limited to information sharing and capacity building, then it would be premature to imply that these inter-regional consultation processes have provided considerable coherence on governance of international migration. One more point to be stated about them is that there is a minimum administration, which means it is up to the participating states to set the agenda of meetings and provisions of declarations. This situation, according to Betts, allows powerful Northern states, which are mostly migrant receiving countries, "to include or exclude partner countries on their own terms" (2008: p. 14). Another common, but at the same time distinctive point about them is that they are state-controlled processes, in which non-state actors are not integrated or, at least, they are outside of the real decision-making process (Channac, 2007).

\subsection{Summary of the chapter}

This chapter was designed to offer a general overview of the global governance of migration and its politics. What we have noticed through the whole chapter is that even though nation-states have already given up controlling the flow of goods and capital to/out of their territories, they are not eager to take the similar steps with the flow of people to their territories. This is to say that autonomy over those who cross the borders is still in the central theme of states' national sovereignty. The logic behind it is very simple, as Gordon states: "people are not bananas...people have different impacts than goods and capital" (2010: p. 1132). Nevertheless, in parallel to states' reluctance, we should have also detected from the discussion of this chapter the growing interest of nation-states towards the global approach to 
international migration, which resembles the glimmering sun from time to time behind the dark clouds. Today, states are already familiar with the increasing complexity of international migration, which has got an unpredictable trans-boundary nature by influencing political, social and economic life in a country of origin, transit and destination, and they obviously recognize that the effective governance of this social phenomenon is not possible on their own. The various formal and informal dialogues and cooperation at the global and inter-regional levels discussed in this chapter are the proof of this recently emerged tendency. For the clarity and better understanding of the issue, there is a need to point out three summarizing characteristics of this nascent global governance.

The first major characteristic, according to Betts, is that global migration governance is emerging as a "bottom-up structure" rather than a "top down treaty based" (2008: p. 12). In contrast to policy areas, which are governed through the formal regime under the Intergovernmental Organization(s), in the global governance of migration the rules do not come from IOs, but from bilateral, regional or inter-regional dialogues between states that share the similar interests. This bottom-up structure leads to an informal and non-binding cooperation at the global level (with the exception of the refugee regime under UNHCR and the labour migration under ILO) and subsequently lets the participant states have a selective approach to the different issues being discussed. As a result, they implement recommendations which meet their instant interests, but disregard those which do not. To put it in a different way, states mostly take an utilitarian approach to migration by giving a priority to their economic interests: while countries of origin are often driven by the desire to increase foreign remittances and to solve the problem of high unemployment, countries of destination try to solve shortages in the labour market by ensuring a highly compliant and flexible workforce (Piper, 2007: p. 9). Hence, there is a need for a top-down treaty based structure for global governance of migration, which, according to Green and Thouez, can be met by the UN's significant initiative (2005). This is to say that for global governance of migration to be effective, there is a need for a rule-based and institutionalized multilateralism, preferably within the UN system.

The second specific attribute is that the global governance of migration is lacking a central coordination. As it is obvious from the chapter, a broad range of global actors, such as 
IOM, ILO, Bern Initiative, RCPs, etc. are dealing with the issue at the same time, but separately. To give an example, all organizations involved in international migration, disregarding their competency area, are striving to provide a dialogue and employ projects in the area of migration and development, without consulting with each other beforehand (Badie, Brauman, Decaux, Devin and Wihtol de Wenden, 2008). Even though the GMG was created in 2006 to establish and enhance the coordination between various agencies involved in international migration, not all actors are participants of this inter-agency framework, in particular RCPs, and its informal structures is not enough to overcome this coordination deficit.

The third and final distinctive characteristic is that even though nation-states are still the relatively dominating actors that shape and influence the process and policies of global migration governance, the engagement of non-state actors, especially civil society actors are gradually increasing. The engagement of the civil society actors in the global governance of migration will profoundly be analyzed in the following chapter. 


\title{
CHAPTER THREE
}

\section{CIVIL SOCIETY ACTORS IN THE GLOBAL GOVERNANCE OF MIGRATION}

\begin{abstract}
בe
"Our times demand a new definition of leadership - global leadership. They demand a new constellation of international cooperation - governments, civil society and private sector, working together for a collective global good" (UN SecretaryGeneral Ban Ki-moon).
\end{abstract}

When I mentioned the main difference between international governance and global governance at the beginning of the second chapter, I stated that in contrast to the international governance, the latter involves non-state actors, civil societies and private sectors in addition to nation states. Thus, the discussion of civil society actors in the global governance of migration is an unavoidable task in this project.

The last two decades of human history have witnessed an increasing engagement of civil society actors in the global governance of many trans-boundary issue areas. Quoting from Karns and Mingst, "power, indeed is less concentrated in states and has diffused to the other actors in global governance" (2004: p. 17). They have emerged as a potential global force - not as powerful as international organizations, national governments and transnational corporations, but nonetheless as independent global actors capable of affecting political agendas and fostering social change (Fries and Walkenhorst, 2010: p. 1-2). In spite of its nascent character and extremely strong state sovereignty factor, the global governance of migration has been going through the same tendency as well. However, the multifaceted structure of the global migration governance and the considerable resistance from nation states against the comprehensive institutional approach towards international migration have had an influence both on the quantity and quality of civil society participation in this policy area. Thus, this chapter is intended to analyze the civil society engagement of the global migration governance by giving an answer to the question "Who, when and where gets access to participate in the global governance of migration?". The arrangement of the question in this way will enable us to be aware of both the level of civil society activities in, and its contributions to, the politics of the 
global governance of migration and it will also help us understand how the nature of international migration politics has shaped civil society participation. The chapter, first, explains what the civil society is, by displaying some useful definitions and approaches, and later clarifies why there is a need for the civil society participation in the global problem-solving, particularly in international migration politics. Finally, the chapter will profoundly discuss the above mentioned question and summarize the general findings of the section.

\subsection{Who are civil society actors?}

The focus on civil society has grown in the 1990s because of concerns with political changes in the post-Cold war period and the unprecedented level of globalization. Even though the term 'civil society' was revivified in the 1990s, it has passed through the history of political ideas and was given various definitions throughout its evolution (Van Rooy, 1998; Nuscheler, 2003). As Van Rooy states, civil society has been described as values and norms, as a space for collective action, as a historical moment, as an anti-hegemony and anti-autocratic state by different scholars in 1980s-1990s (1998: p. 12-27). In all contemporary definitions the civil society is described as an independent of state system and as outside of political parties. For instance, Charles Taylor defined civil society as "a web of autonomous associations independent of the state which, bound together in matters of concern by mere existence or action, could have an affect on public policy" (1991: p. 52). Scholte described civil society as a political arena where associations of citizens seek, from outside of political parties, to shape the rules that govern one or the other aspect of their social life (2002; 2007). According to Van Rooy, civil society covers "all those organizations that fill in the space between the family, and the state and the market" (1998: p.1). To make a quotation from Wapner, "people engage in spontaneous, customary and non-legalistic forms of association to pursue common goals" (1996: p. 5). According to these definitions we can truly assume that civil society comprises only groups which are neither governments nor profit-seeking private units. This general assumption, very often, makes us think of civil society as a synonym to non-governmental organizations (NGOs). Clarifying this misconception and pointing out the distinction between NGOs and civil society, Karns and Mignst describe the latter as "a broader concept that 
encompasses all organizations and associations that exist outside of the state and the market" (2004: p. 223). This is to say that civil society takes a range of forms, including NGOs. From this perspective we can consider NGOs, academic institutions, think tank groups, labor unions, associations, demonstration groups, religious groups, women's networks, ethnic associations, cultural groups, youth and sport associations and student networks, etc. as civil society actors. However, there is a need to put different types of civil society actors into groups and characterize them according to what they can or what they do. Tarrow (2001) has distinguished between social movements, non-governmental organizations and networks of associations. While NGOs have access to interact with officials in decision-making, social movements lack this access. And networks bring together different NGOs and social movements involved in dealing with particular issues to help each other and share practices (Kalm and Piper, 2011: p. 6). Regarding their activities civil society actors are characterized as advocacy (agenda setting and policy formulation) and operational (service delivery, policy implementation and monitoring) (de Jonge Oudraat and Haufler, in Fries and Walkenhorst, 2010: p. 18).

Regarding its nature, in general, civil society is perceived as a good thing to have. They are believed to improve development, promote respect for human rights, produce equity, construct democracy and increase public participation in the global institutions (Nuscheller, 2003; Tallberg and Uhlin, 2011). However, this should not imply that civil societies are pure like fresh milk. As Robinson and White states, "civil societies contain repression as well as democracy, conflict as well as cooperation, vice as well as virtue; they can be motivated by sectional greed as much as social interest" (Robinson and White, 1997: p. 3). Or quoting from Keck, "civil society activist in global governance institutions represent positions rather than populations, ideas rather than constituencies" (2004: p. 45). Nevertheless, in spite of these possible shortcomings, civil societies attach a sense of justice to the politics of the global governance. Thus "having civil society, warts and all, is better than not" (Van Rooy, 1998: p. 18).

To sum up the discussion of civil society definitions and various approaches, we can point out the following general characteristics of civil society:

- It is independent of states and does not include profit-seeking units or governments

- It takes a range of forms, not just the form of NGOs 
- Mostly it is a good thing to have; it might have some shortcomings, but it does not cause harm or damage to the society

- The individual is primary in civil society.

\subsection{Why is there a need for civil society engagement?}

In the growing amount of literature on the subject of global governance, and on the agendas of dozens of international conferences on various global issues, it has been stressed that there is an increasing need for civil society engagement in the politics of intergovernmental institutions or inter-state cooperation. Florini has stated this need as follows: "the world badly needs someone to act as the global conscience, to represent broad public interests that do not readily fall under the purview of individual territorial states or that states have shown themselves wont to ignore" (2000: p. 4). This key role is believed to be performed by various civil society actors.

As chapter two has already explained, the intergovernmental institutions are both the key actors of the global governance and the main global arena where the comprehensive and normative rules and decisions come from. It has been argued that these intergovernmental institutions have considerable democracy shortfalls regarding transparency, accountability, legitimacy and public participation, and that civil society engagement in the global governance can remedy these deficiencies (Lipschutz, 1992; Risse, 2002; Scholte, 2002, 2005, 2007; Pattberg, 2006; Steffek and Nanz, 2008). For example, Scholte suggests that "civil society associations offer significant possibilities to increase democratic accountability in global regulatory arrangements" (2005: p. 88-89). In the same line, Steffek and Nanz offer that “organized civil society has the potential to function as a 'transmission belt' between global citizenry and the institutions of global governance" (2008: p. 3). The above mentioned deficits of intergovernmental institutions and the following promises of civil societies to redress these shortfalls explain why there is a need for civil society participation in the global governance.

First of all, those who are affected by particular decisions of the global governance are not officially recognized under international law to participate in the decision making at the international level, which puts them far away from discussions and makes it hard to feel a sense 
of justice being done (Fries and Walkenhorst, 2010: p. 1-10). However, through direct (having representation on the board of global institutions) and indirect (lobbying on state delegations) participation in global governance arrangements, civil society actors can shorten this remoteness between ordinary citizens and the global rule makers by letting their voice be heard and considered in regional and global forums or/and in annual meetings of intergovernmental institutions where the heads and delegations of states and institutions come together and make decisions. This will also indirectly increase a public participation in international institutions and other global governance arrangements (Tallberg and Uhlin, 2011: p. 3)

Second, as Scholte submits, "often citizens are not aware what decisions are taken by whom and .... with what expected results" (2002: p.290). Hardly any international institution can build an apparatus which would be able to enlighten every single citizen what decisions and why they are made within the global governance of a particular issue. Nevertheless, there is no need for such an apparatus, because civil society actors can increase citizen awareness of the actions and decisions of international institutions by carrying out TV or radio projects, publishing booklets and brochures or offering seminars and workshops to those marginalized groups.

Third, civil societies do not only increase public participation and awareness in global governance, but they can also push international agencies and states to be transparent and accountable for their decisions and policies. As Nuscheler states, "in keeping a watchful eye on the doings of international organizations they are more effective than parliamentary committees" (2003: p. 6). This is to say that civil societies keep their observant eyes on intergovernmental institutions and states by monitoring the implementation of particular decisions by them and by making reports on their non-compliance. These reports might also be useful for intergovernmental institutions to evaluate member states' compliance to their commitments and set the agendas for discussions.

Finally, as it is already mentioned, one of the democracy deficits of intergovernmental institutions is the legitimacy problem. Regarding this institutional limitation Scholte argues that "legitimate rule prevails when people acknowledge that an authority has a right to govern and 
that they have a duty to obey its directives" (2002: p. 294). To say it in a different way, intergovernmental institutions are legitimate when they get full respect from people. To get this respect, they have to develop public participation by interaction with civil society groups and let their opinions be considered by nation states while making decisions.

After mapping out these potential contributions of civil society groups to global governance, we can truly assume the following normative presumption about the global governance of migration. To be democratic, the global governance of migration should not only have an equal representation of all countries, but also involve non-state actors and allow direct participation of people, especially those who are affected, in the decision-making process. This is to say that the global governance of migration has to be legitimate, transparent and participative by allowing civil society actors to play an effective role in decision-making together with states and IGOs so that they can provide the above mentioned potential contributions to the governance of this complex and trans-boundary social phenomenon. Hereby, the next section is intended to assess the empirical viability of this normative assumption about civil society participation in and its influence on the global governance of migration.

\subsection{Who, where and when gets access to participate?}

In their research Grugel and Piper (2007) argued that in the case of global governance of migration where no formal international standards exist or there is a lot of resistance towards them by nation states, then only well organized civil society actors can attach social justice to the agenda for marginalized groups. They can set or at least influence the agenda of international politics of migration, provide credible information (migration data and knowledge) for international debates, impose moral authority and legitimacy to the global arrangements, and monitor the implementation of policies by nation states. However, it is important to state that the quantity and quality of civil society engagement in the global governance of any particular issue is heavily dependent on the political environment. As Risse submits, civil society actors can act properly and increase their influence if they act in an environment which is highly structured by international institutions (2002: p. 264-65). This lets us assume that civil society participation in the politics of international migration, at the regional and global level, is not 
developed enough since they act in an environment which is characterized with a less developed institutional structure under the global governance of migration. In his research, where civil society practice in the international migration policy up until 2003 is profoundly analyzed, Colleen Thouez summarized that because of the highly controversial nature of both international migration as a social phenomenon and international politics of migration, civil society activity on international migration policy development had been limited (Thouez: p. 23). Since 2003, a lot of independent initiatives, inter-regional consultation mechanisms and global forums on international migration have been arranged at the global level, and thus, there is a need to analyze their interaction with civil society actors, which are involved in the politics of international migration. To do so, there are two major concerns which have to be mentioned and scrutinized in the following discussions.

The first concern of this section pertains to the question of where and when civil society actors get access to participate in the international politics of the global migration. It is because the recent researches on civil societies (such as Steffek and Nanz, 2008, Green 2010, Scholte 2011, Tallberg and Uhlin 2011) show that even in the policy areas where the amount of civil society actors is very high, their participation in the decision-making is extremely infrequent in comparison to the stage of policy formulation and implementation. As Tallbeerg and Uhlin state, "once we get to the stage of decision-making, participation by civil societies is exceedingly rare" (2011: p. 8). To get an answer to this concern there is a need to look at the access granted to civil society actors by the different global arrangements (both formal and informal) of international migration. Regarding the institutions of the UN system discussed in the previous chapter, civil society actors are welcomed. However, they mostly have access just to operational activities when immediate and concrete needs of the people are concerned. For instance, with respect to refugee and asylum protection under the UNHCR, civil society actors are acting as service providers by offering shelter, clothing, food, education or legal counseling to refugees, asylum seekers and displaced people (Thouez: p. 14-15, Piper, 2007). Concerning the IOM, Piper argues that it has no official mechanism to engage with civil society actors and consider their critics and advocacy, even though it is an inter-governmental organization. Like the UN agencies it also welcomes operational INGO and NGOs (Piper 2007: p. 11-12). The ILO 
with its tripartite structure can be an exception here by granting direct participation to the trade unions of workers in policy making together with governments and employer organizations. However, as Kalm and Piper submit, trade unions "have historically only included a minority of organized workers, to the exclusion of informal, female and migrant workers" (2010: p. 13). Borrowing from Piper, (2007: p. 16) "trade unions have remained nationally oriented and hierarchically structured" which does not let them deal with complexity and scale of labor migration. Regarding the independent ad-hoc initiatives, with respect to the GFMD, there have been held civil society days in addition to annual governmental meetings. However, those civil society days were outside of the governmental meetings and thus civil society actors were not able to influence either the agenda or the positions of participating governments in the discussions. This was the main reason why civil society actors required the GFMD to be incorporated into the UN system, since the latter had an article in its Charter which encourages the civil society participation. Since the GFMD is still outside of the UN system, because of the high resistance of the migrant receiving developed countries, the article of the UN does not apply to the GFMD. Nevertheless, due to the continuing civil society pressure and critics, after Brussels and Manila forums, the civil society groups were able to participate in a joint meeting with government officials in the Athens forum in 2009 and produce a "Joint Civil Society Declaration and Recommendations on Migration, Development and Human Rights And the Future of the Global Forum on Migration and Development" ${ }^{22}$ in consultation with the People's Global Action on Migration and Development (Ibid: p. 14). This is to say that the access to policy discussions and a direct participation opportunity (agenda setting, policy advocacy) for civil society actors has been gradually developed in the informal global arrangements, in particular within GFMD, which is the most comprehensive and the largest informal global platform for dialogue and cooperation on international migration and development.

The second concern of this section relates to the question of who gets access to participate in the global governance of migration. This is to know to which extent civil society actors of international migration represent the interests of the people who are affected by the

\footnotetext{
${ }^{22}$ For a detailed information and full text see the link: http://www.mfasia.org/pga/statements/Joint\%20Civil\%20Society\%20Declaration\%20Athens without\%20signatori es.pdf
} 
decision of the global arrangements. Regarding this concern, the researches show that INGOs and networks of civil society associations are dominating, while social movements of migrants are lacking. It might be because of the threat of being detected by hosting governments and sent to their home countries, that marginalized groups, in particular, irregular migrants are afraid of. This means that civil society actors' participation in the global governance of migration is far from evenly balanced. Stressing the importance of social movements of migrants, Piper argues that "in order to really make a difference to people on the ground - here the migrants themselves - their voices need to be heard" (2007: p. 8).

Thouez (2003) has distinguished operational and advocacy INGOs involved in the politics of international migration. Among those who are actively participating in advocacy the Migrants Rights International (MRI) has to be mentioned first. Being known as "International Migrants Right Watch Committee" until 2000, the MRI was established in 1994 during the Cairo International Conference on Population and Development to promote the respect to human rights of migrants, and influence the governments to treat migrant as a human being who is equally entailed with fundamental human rights rather than approaching them from an economic angle as a commodity. Together with other civil society actors the MRI has been involved in the advocacy campaigns to push the GFMD and its participant governments to stop viewing the migration as a substitute for development. This concern is stressed out in the statement of the Civil Society Days to the GFMD's participant governments in the fourth annual Forum in Mexico, in 2010 as follows:

"As we meet for the fourth time, we reiterate that while voluntary migration can contribute in important ways to development, migration is not and cannot be used as a substitute for development.... We emphasize that the right to development is a basic human right; it is far more than economic growth. It is a holistic principle that guarantees the social, economic and cultural rights of all, including human rights. It must include opportunities for human growth, the access to descent work at home and abroad, health care, education, security of life and person and full participation in political and social process. In short, there can be no real development without human rights" (GFMD, 2010: p. 1-2).

As it is stated on its official website, one of the MRI's objectives has been to advocate for universal ratification and effective implementation of the UN International Convention on 
the Protection of the Rights of Migrant Workers and Members of Their Families $(\mathrm{CMW})^{23}$. Evaluating its activity towards this aim, the MRI should be considered half successful. On one hand, it was due to the MRI advocacy activities that the CMW came into force in 2003, after 13 years since it was adopted and today, 44 of the UN member states have ratified it. As Grugel and Piper (2007: p. 50) mentioned, until the mid-1990s it was very difficult to find a copy or a translation of the text, let alone no UN agency tried to promote the convention and its implementation. Here the MRI has played the role of a norm entrepreneur by stressing out the respect to fundamental human rights. On the other hand, as a norm entrepreneur the MRI could not reach the tipping point that would lead to a "norm cascade" followed by a "norm internationalization". According to Finnemore and Sikkink (1998: p. 895-97) for a norm to pass to the stage of a "norm cascade" it has to be adopted by a critical mass of states. It is argued that " $a$ combination of pressure for conformity, desire to enhance international legitimation and the desire of state leaders to enhance their self-esteem" can facilitate a norm cascade (Ibid: $p$. 895). In the case of CMW, a critical mass relates to the migrant receiving developed countries of the industrialized north, none of which is among those 44 countries which have ratified the Convention, and most of which are not inclined to enhancing their self-esteem regarding international migration. From this perspective, unless the MRI and other advocacy civil society actors can achieve the ratification of this convention by this critical mass of states, the internationalization and full implementation of the CMW's provisions do not seem to be possible.

In contrast to MRI, which is fully devoted to migrants' rights, other well known advocacy civil society actors such as Amnesty International and Human Rights Watch are not specialized particularly on migrants' problems. They are dealing with complains about the violations of human rights which are granted under the several Conventions, in particular, the Universal Declaration of Human Rights. Migrants' rights hold one minor corner of their advocacy activities at the global level. Regarding the Human Rights Watch, it is stated in its official website that as a non-profit INGO, the Human Rights Watch is intended to give voice to the oppressed and hold

\footnotetext{
${ }^{23}$ See the official website: http://www.migrantwatch.org/objectives.html
} 
oppressors accountable for their crimes where human rights are violated. ${ }^{24}$ In its report on migrants' rights in 2010, the Human Rights Watch stated the result of its monitoring on immigration policies of migrant receiving and transit countries and pointed out the human right abuses against migrants. It also made its recommendations on each oppressor country and called them to be accountable for the violations of migrants' human rights (Human Rights Watch, 2010). Another active civil society actor that is involved in the advocacy of migrants' rights at the global level is the "December $18^{\prime 25}$, which was established in 1999 and has been advocating for the ratification and implementation of CMW together with the MRI. Its' main goal is "to ensure that human rights of all migrants are known, recognized and protected effectively, and that the environment is created for migrants to be full participants in any society" (December 18, Annual Report, 2009: p. 3). Starting from 2006 the December 18 has been arranging a broadcast - Radio 1812 - on the context of International Migration Day (18th of December), through 175 radio stations in 48 countries in all world regions, to let migrants' voices be heard across the world. One more example to the advocacy civil society actors of the global migration governance is the Migrants Forum in Asia (MFA), which was officially established in 1994, and today it encompasses non-government organizations, associations and trade unions of migrant workers in Asia. With the slogan of "migrants' rights are human rights" the MFA is advocating, as a network of various migration related civil society association and NGOs, for the rights and welfare of migrant workers in hosting countries both at a regional level and a global level through the ILO. Those are the main civil society actors who have direct access to the politics of international migration to set the agenda of the discussion, and tools for policy advocacy and formulation within the global arrangements dealing with the international migration. In addition to these advocacy civil society actors, there are some operational and service providing civil societies that work at the global level. To give some examples, International Catholic Migration Commission (it recently started to be involved also in some advocacy for human rights of migrants), International Committee of the Red Cross, Norwegian Refugee Council, and Forced Migration Online should be mentioned. Since they do

\footnotetext{
${ }^{24}$ See the official website: http://www.hrw.org/en/about

${ }^{25}$ The name of the organization is refers to the day when the General Assembly of the United Nations adopted the CMW. Today, the 18th of December is known as International Migrants Day.
} 
not have direct access to the policy discussions and cannot contribute to policy formulation and implementation as much as the advocacy civil societies do, there is no urgent need to discuss their operational activities here.

To conclude the discussion, in comparison to many other trans-boundary issue areas, civil society participation in the international migration started to shine at the beginning of this millennium because of the highly controversial nature of this social phenomenon. And concerning the existing political environment where civil society actors participate, we can truly assume that civil societies could have given more contributions to the global governance of migration if there were more formal and institutional arrangements.

\subsection{Summary of the chapter}

The main task of this chapter was to examine the civil society participation in the politics of the global migration governance in order to evaluate the viability of the normative assumption about the potential civil society contributions to this policy area. Starting from the definitions of civil society and their normative promises the chapter mapped out both operational and advocacy civil society actors involved in the global governance of migration, with particular focus on the latter, and also analyzed the political environment where those actors participate. To make a concluding virtual picture out of these discussions, there is a need to point out the general findings of this chapter and offer concluding remarks.

First of all, as it is obvious from the above mentioned discussions, the civil society activities in the politics of the global migration governance do not cover the whole migration policy field or do not carry advocacy for all marginalized groups. As Thouez argues, "most civil society actors in the area focus on the one aspect of migration advocacy and policy development such as human rights of migrants or trafficking in human beings" (2003: p. 2).

Second, the access granted to civil society actors of international migration by the global arrangements, both through the UN system and outside, has been relatively limited so far. In his recent project, Steffek (2010) scrutinized civil society participation in more than 30 global institutions across various issue areas and confirmed that while there is good access for civil society actors to take part in official negotiations with governments in the decision-making 
process, in policy areas such as environment, climate change and trade, the international institutions, concerning international politics of global migration, still remain closed to civil society actors in many respects, in particular governmental meetings and the decision-making process.

Third, civil society participation in the global governance of migration is far from equally balanced. Among those who participate in the policy advocacy within the global arrangements, well-organized and well-funded INGOs, which were mostly established in the developed countries of North or migrant receiving countries, are dominating, whereas marginalized groups from developing countries are highly underrepresented. To make an exception, "December 18" started to represent those marginalized groups, especially irregular migrants, by making their voice heard through its broadcasts in many countries. However, it happens only once in a year in the context of International Migration Day and their voices are heard mostly in migrant sending developing and less developed countries, where their voice are broadcasted, rather than in migrant receiving countries.

Fourth, civil societies involved in this policy area are mostly operational actors, which focus on service delivery and pedagogical work to marginalized groups. This is to say that operational civil society actors, that are plentiful, are dealing with the results of the international politics of migration, and they are not able to shape these policies as much as advocacy civil societies, which are not so much in this policy field, can.

And finally, regarding advocacy civil society actors, their participation in the global governance of migration is considerably more extensive in the implementation and monitoring of policy and/or in agenda setting than in the decision-making stage, which is the politically most important stage in international cooperation. It has already been mentioned that only recently have advocacy civil society actors been given a chance to negotiate with government representatives in annual meetings of the GFMD and to have their concerns be taken into consideration by the rule-makers in the decision-making process. However, this resembles a couple of grains of sand on a huge beach and there is a need for much more civil society participation in the decision-making process of the international migration politics within the global cooperation arrangements. Moreover, participation of civil society actors in the decision- 
making process has to be enhanced in the formal institutional arrangements, which are the main global arena where the universal rules and norms come from. 


\section{CHAPTER FOUR}

\section{COMPARISON WITH OTHER POLICY AREAS}

The solution lies not in turning one's back on globalization, but in learning how to manage it. In other words, there is a crying need for better global governance (UN Deputy Secretary-General Louise Frechette, 1998 quoted from Dogson, Lee and Drager, 2002: p. 5).

After the discussions of the existing framework and international politics of the global governance of migration, and the examination of the civil society participation within this global governance system, the following question might bother our minds. Is it possible to achieve effective, collaborative and fair global governance for the regulation of the international migration? To offer an answer to this concern there is need to have a very brief look at the global governance of other trans-boundary issue areas, such as within climate change, health and trade. Those policy areas have got relatively the same degree of globalization and international attention like migration did, however, the latter has not been able to reach the same degree of institutionalization at the global level like climate change, health and trade have. Thus it would be interesting and useful to know what has made them successful in contrast to the international migration.

In comparison to the previous ones, this chapter is reasonably short. Taking into account the general findings of the second and third chapters, and looking through the global framework for the governance of the above mentioned policy areas, this chapter highlights two important lessons to be learnt from the global governance of these policy areas and applied to the global governance of migration.

\subsection{The lessons to be learnt from the global governance of climate change, health and trade}

The main attribute that characterizes these three different policy areas is that the comprehensive norms, rules and principles come from the formal institutional global 
arrangements, and they are regulated under the international regimes. Taking into account the standard definition, regimes are:

"sets of implicit or explicit principles, norms, rules and decision-making procedures around which actors' expectations converge in a given area of international relations. Principles are beliefs of fact, causation, and rectitude. Norms are standards of behavior defined in terms of rights and obligations. Rules are specific proscriptions for action. Decision-making procedures are prevailing practices for making and implementing collective choice". (Quoted from Krasner in Vogler, 1995: p. 22)

To put it in other words, the international politics of these policy areas take place within highly structured institutional frameworks. The gradually increasing trans-boundary nature of these issue areas and decreasing power of states to deal with these problems alone enlarged the gap between the existing problems and governance, which later was fulfilled by the global institutional arrangements. The global devastating threats of environmentally destructive activities all around the world pushed the nation states to cooperate at the global level and establish a universal approach to the global climate change, even though the commitments to the requirements of this comprehensive approach imposed very high economic costs on them. To borrow from Caroline Jackson, "even the darkest skeptic has to admit that when it comes to environment policy it makes sense for states to cooperate and do things in common" (Jackson, 2003: p.1). Regarding the health and trade, an increasing interdependence between states, and a productivity of solving problems through the collaboration at the regional and global level have attached institutionalized global governance to these trans-boundary issue areas. One can argue that from the beginning of the 1990s international migration has also got a highly transboundary nature, which would also lead to the establishment of a similar formal institutionalized framework. However, the influence of migration in the hosting countries is very complex and thus, states have so far been very sensitive in terms of tightening their hands with the binding rules of international law. Borrowing from Jenifer Gordon (2010: p. 1132), "unlike imported computer or cars, human beings put down roots, meet partners, have children who enter schools, speak languages, get sick, practice religions, have cultural beliefs that differ from those of the communities they enter and so on" which draws a clear distinctive line between migration and the above mentioned three issue areas. 
The United Nations Framework Convention on Climate Change (FCCC), which was formally adopted in 1992, in Rio Summit, and brings together the member countries every year in Conference of Parties (COP) since 1995, is the major global climate change governance instrument. The most vital outcome of this framework is the Kyoto Protocol, which was adopted in 1997 and entered into force in 2005 (Bernauer and Schaffer, 2010: p. 9-10). Based on the principles of "polluter pays" ${ }^{26}$ and "historical responsibility"27 the Kyoto Protocol has determined strict commitments for those who have ratified it. Concerning health and trade, respectively the World Health Organization (WHO), which was established after the Second World War, and World Trade Organization (WTO), which replaced The General Agreements on Tariff and Trade (GATT) in 1995 are the main normative decision-making and standard setting global arrangements through which nation states cooperate at the global level based on the formal structures. The WTO has a very highly structured institutional framework which includes annual ministerial meetings where universal normative decisions are taken; dispute settlement body which manage trade disputes between member states; and trade policy review body which monitors national trade policies of its members (Lee, Sridhar and Patel, 2009: p. 416-17). Concerning the global governance of health, as it is stated on the official website, the WHO is responsible for providing leadership on global health matters, shaping the health research agenda, setting norms and standards, articulating evidence-based policy options, providing technical support to countries and monitoring and accessing health trends. ${ }^{28}$

The second common characteristic of these global issue areas is the high level of the civil society involvement, regarding both the quantity and quality. The significance of broadbased public participation, which is achieved through civil society engagement, has been a constant theme in the international politics of these issue areas (Green and Thouez, 2005: p. 89). Regarding global arrangements dealing with the climate change David Runnals mentioned that "the international environmental institutions have each evolved differently, but they all

\footnotetext{
${ }^{26}$ The polluter pays princple, in environmental law, is enacted to make the party responsible for producing pollution for paying for the damage done to the natural environment.

${ }^{27}$ Historical responsibility principle, which was proposed by the Brazilian government at the beginning of the 1990s, means that states should be respoblible directly for their proportional historic GHGs emmision to the atmosphere, which makes developed countries of the economic North more responsible.

${ }^{28}$ See the official website: http://www.who.int/about/en/
} 
have something in common; they are unusually open, both to civil society actors and to the business community". (Quoted in Najam, Papa and Taijab, 2006: V). Even though the ministerial meetings of the WTO had been closed to civil society actors for a long time, after the 1999 Seattle demonstration against the WTO's annual ministerial summit, the interaction with civil society actors and granting them with good access to policy discussions have turned to hold a very important corner of the WTO policy. Evaluating civil society participation within the global governance of trade Jens Steffek and Ulrike Ehling concluded that the WTO, when compared with the GATT47, "has made remarkable progress over the last ten years" and now "officially acknowledges civil society actors as significant and legitimate interlocutors" (Steffek and Ehling, 2005: p. 26). The same tendency has been observed in the global governance of health through the WHO during the last two decades. In her latest research about the global health governance Kelley Lee argues that even though civil society access to formal discussions within the WHO is limited for some substantive reasons, their informal participation has been highly effective and has played the biggest roles in initiating, formulating and implementing formal rules (Lee, 2010: 16-18).

Taking into account these strengths, there are two very important lessons to be learnt and applied to the global governance of migration. The first lesson is to bring a "top down" treaty based system to the international politics of migration. To put it in other words, there should be established an international migration regime like international trade, environment and health regimes. Talking about international regime Steffen Castles highlights its four major elements: a set of legal instruments, a number of institutions, a set of international norms and a set of policies (Castles in GCIM, 2004: p. 15-17). As it is obvious from the second chapter, only one area of international migration - refugee, asylum and displaced people - encompasses these four elements. Therefore, there is a need for a comprehensive international migration regime, which would include all areas of migration rather than one or two. This might be managed in two ways: either the creation of a brand new organization, such as the World Migration Organization or incorporation of the IOM to the UN system. Concerning the first way, the establishment of a totally new intergovernmental organization would probably reduce the problems of coordination and overlap in the international migration policy debates. Jagdish 
Bhagwati argued that "the world badly needs enlightened immigration policies and the best practices to be spread and codified" and he proposed the establishment of a World Migration Organization similar with the WTO model (Bhagwati, 2004: p. 218). However, in the environment where dozens of formal and informal global arrangements are dealing separately with different aspects of the international migration, the creation of a brand new organization would be both time consuming and a painstaking process. The low level of ratifications of 1947 and 1975 ILO and 1990 the UN labor conventions, and the resistance against formal institutional debates by many states', especially migrant receiving developed countries, let us assume that the World Migration Organization would not be welcomed by many nation states. As Bimal Ghosh argues, "governments seem hardly anxious to start a whole new organization to deal with international migration" (Ghosh, 2005: p. 14). Nevertheless, the second way, the incorporation of the IOM, which has the broadest mandate for any migration issue in operational and service providing ways, to the UN system, which has a well developed international treaty based legal system, seems both logical and realistic. As it has already been mentioned in the previous chapters, the IOM does not have a legal mandate for producing normative and legally binding decisions, but it does encompass migration as a whole unlike any other migration institutions both within and outside of the UN system. Thus, there are two unconnected pieces of one clear picture in front of us, which need to be put together. On one hand the IOM lacks a legal mandate; on the other hand the UN does not have any specialized agency, which deals with migration as a whole rather than one or two aspects. Hereby, the incorporation of the IOM to the UN system and attachment of a broad legal mandate to it would pave the way for the establishment of a comprehensive top down treaty based institutional global governance for the international migration. Newland argues that this incorporation can happen either directly, by the vote of the IOM Council or the UN General Assembly, or indirectly, "by a gradual rapprochement between IOM and other agencies with migration responsibilities" (2005: p. 15).

The second vital lesson to be learnt is to broaden the public participation through more active interaction with civil society actors. As it has already been mentioned, civil society participation in the global governance of migration has been very limited and mostly focused 
on operational activities or/and has not been granted with a good access to policy discussions in global arrangements. It is a widespread reality that environmental civil society actors have been very critical in increasing the public awareness of the global climate change, advancing policy principles, lobbying for their acceptance and monitoring their implementation (Thouez, 2003: p. 20-21). The same tendency has been observed in the global governance of trade and health as well. Civil society actors can play the similar role in setting the agendas of international migration politics, advancing guiding principles and monitoring their implementation, and putting on the table interests of those who are affected if an appropriate international environment is established. It directly depends on the establishment of an institutional legal framework. The incorporation of the IOM to the UN system will increase the civil society participation in the politics of international migration, since the UN charter demands its specialized institutions to open their closed doors to civil society actors and develop the interaction process with them.

To summarize, it is obviously difficult to predict whether the global governance of migration will remain informal or step into the formal stage of cooperation. However, there is one reality and that is none of these problems are insoluble if nation states are willing to sacrifice a small portion of their sovereignty over deciding who, when and under which conditions can pass their borders, and establish a brand new organization or include the IOM into the UN system and supply it with a strong normative decision-making mandate. If we remember that the history is repeating mistakes, then this willingness will not occur unless governments encounter an obvious danger resulted from regulating human flows loosely. 


\title{
THEORETICAL IMPLICATIONS OF INTERNATIONAL MIGRATION POLITICS AND ANALYSIS
}

\begin{abstract}
"Explicitly or implicitly, international relations theories are also theories of global governance, addressing questions of who governs, how governance occurs and with what effects, at different points in the time". (Karns and Mignst, 200: p. 35)
\end{abstract}

The previous chapters have mapped out the general picture of the global governance of migration, described the global arrangements (formal and informal) involved in this policy area, examined civil society participation in the politics of international migration, and pointed out the highly structured institutional governance of climate change, trade and health versus international migration. Now, it is time to find out why international migration, today, is regulated as it is. To do so, in this chapter the main arguments of two major theories - Realism, and Institutionalism - will be applied to see what each of these theories can say about the existing state of the global governance of migration. The reason to why two theories are chosen but nor one or more than two is that as I have already mentioned in the introduction chapter, there is no single theory that can implicitly or explicitly explain the politics of international migration. Therefore, if discussions are based just on one theoretical approach, then only one side of the coin would be explained and the result would be partial. Regarding the concerns why exactly these two theories are chosen but not others, my explanation is that each of other potential theoretical approaches has considerable limitations that prevent them to be explicitly or implicitly applied to the international migration politics. For example, Globalization theory, which claims that sovereignty and regulatory power of nation states, in many policy areas, have been challenged and weekend by globalization and its socio-economic forces, is not applicable to explain the global governance of migration, where states are still the dominant actors and the notion of sovereignty is still a very critical element. Concerning Constructivism, which has become one of the dominant theoretical approaches in the studies of international relations, its national identity approach, which argues that history, culture, social cleavages and perception 
of national identity of each country (society) form and shape policy choices of nation states, in our case independent migration policies, falls short to explain how different countries with a specific historical and cultural background established almost the same (restrictive) migration policies. And concerning the liberal economic theories of international relations, which argue that an increasing economic interdependence among nation states leaves no choice for them rather than cooperation, cannot explain a paradoxical situation, why states are very reluctant to liberalize the issue of migration which is highly interconnected with the flows of capital, service and goods. As it is obvious, if applied, each of these theories would neglect the role of states and the notion of sovereignty in the politics of international migration and hence we would not be able to get a realistic (here the word realistic does not refer to Realism) picture of the issue. Therefore, I preferred here to apply the actor-oriented theories of international relations for a better understanding of the politics of global migration governance. In this case the choice of realism and Institutionalism, which emphasizes the importance of states in contemporary international relations, but differ from each other concerning how they assume the relationship between a state and an international institution and the conditions under which states form an international regime, is promising. After the discussions of each theoretical explanation in a comparative way, the chapter will finally offer a general summary that highlights a dominant theoretical approach, which can best explain the politics of international migration.

\subsection{Realist approach}

As a well-established grand theory with its rich theoretical traditions, realism has always been one of the central approaches in the realm of international relations. It was born and raised in Europe and grew up in the USA (Jorgensen, 2010: p. 79). Even though realism has lost its dominance in the age of globalization and with the spread of liberal ideas, it still has a lot to say about the contemporary issues when there is a conflicting situation in the international relations. Therefore, realism (both Classical Realism and Neorealism) is one of the most suitable theoretical approaches here to explain the complex politics of international migration, where nation-states are mostly in conflict (confrontation of policies) rather than in cooperation. 
Before moving to the analysis of the global governance of migration from the view-point of the realist approach, there is a need to look through its main characteristics and arguments about the international relations.

First of all, realism assumes international relations as a struggle for power among selfinterested nation-states. As Gillian Youngs argues, "the realist tradition has always emphasized state-to-state relations, interpreting power as the pursuit of state interests and focusing centrally on the politics of diplomacy" (Youngs, 1999: p. 17). Second, sovereignty has always been a central concept in the realist approach to international relations and has been viewed as an identity that is tied to the territorial nature and national authority of states in the international arena. Third, national interests, security, power balance and self-determined rational action are also central concepts that the realist scholars emphasize when they explain states' behavior in international relations (Dunne, Kurki and Smith, 2007; Jorgensen, 2010). Forth, realism assumes state as a rational and unitary actor, which is the most important and principal actor of international affairs (Meyers, 2000: p. 1263-65). To put it in other words, in an anarchical system of international relations, where there is not a single world authority or world police, sovereign nation-state acts as a rational actor by minimizing its losses and maximizing its benefits which is best consistent with its perceived national interests. Fifth, in realist approach, according to Rosenau and Durfee, the issue of security is much more important than economics and the latter is more important than human rights. (2000: p. 1516). Thus, in the case of choice between human rights and economic interests states will give a preference to the latter, and when states are forced to make a choice between security and economic interests, they will rationally choose their security. And finally, concerning globalization process, which extremely characterizes the nature of the contemporary international relations including international migration as one of its development products, the realist approach argues that it is highly dependent on, and shaped by, the national interests and decisive decisions of global powers. To explain it more, the political and economic power distribution among states determines the structure and policies of contemporary international affairs, and it also shapes the behaviors of week states. 
In the area of international migration, which should be conceived as an anarchical in the sense that there is not any single global authority, the above mentioned realist arguments offer us very important analytical utilities to explain why the global governance of migration is week and marginalized in spite of its growing trans-boundary nature in a globalized world. First of all, taking into account the "national interests" argument of the realist theory, we can assume that nation states are very keen to set up their own independent migration policies on the basis of effort to maximize their security and economic interests. And since the main migrant receiving countries are the developed industries of North, the realist scholars would claim that namely those powerful states determine and shape the international politics of migration, as well as the scope of international migration. As it is obvious from the second chapter of this project and the recent academic researches, (see, for example, Badie, Brauman, Decaux, Devin and Wihtol de Wenden, 2008) the countries to which people would like to go, which are mostly in the North America, Europe and partly in the rich oil producing gulf region, restrict entry. This means that borrowing from Zolberg, "in the final analysis, it is the policies of potential receivers which determine whether movement can take place and of what kind" (1989: p. 406). Based on their economic interest, they mostly receive desirable migrants and restrict the entrance of undesirable migrants who cannot offer economic benefit to the industries, and who is perceived as a threat to their domestic societies.

Second, the notions of nation-state and sovereignty are critically important and key factors in the realm of international migration politics. As it is mentioned elsewhere in this project, migration does not only have an impact on the economic and political spheres within the hosting countries, but it also affects the domestic culture and national identity of the receiving societies, which stand at the core of national statehood. Therefore, controlling who can enter a state and who cannot is perceived as one of the few remaining significant elements of a state sovereignty in nowadays international relations.

Third, the concept of security, which is especially emphasized by the realist scholars, is much more influential factor, which shapes the policies of independent states within the framework of the global migration governance. For the clarity, security here should not be understood as an assurance of the fact that there is not a fear of any armed attack against a 
state, but it should be understood in a broad way as an assurance of the absence of societal fears against a domestic society. During the last decade, the notion of security has become very dominant attribute through which migration is viewed in Western societies. As a matter of fact, the GCIM, which was set up by the UN to formulate a comprehensive approach to the governance of international migration, points out the role of security concept in this policy field as follows: "In a number of destination countries, host societies have become increasingly fearful about the presence of migrant communities, especially those with unfamiliar cultures that come from parts of the world associated with extremism and violence" (GCIM, 2005, p. 8). From this statement we can imply that in the Western societies there is fear and uncertainty over migrants coming from the South, and these fear and uncertainty shape the immigration policies of states. To give an example of the EU, the rise of anti-immigrant nationalist parties in Swedish and Finnish parliaments after the recent elections in 2010 and 2011 respectively, the EU's security oriented very restrictive migration policy towards the nationals of the third world countries, very strict border controls and an increasing barbwire on the external EU borders can be perceived as the signs of the importance of security perception, which let us assume that the security has become a significant state priority in many policy areas, in particular migration issues. One more fact that makes this very realistic approach about security concept sound more logical is probably the "9/11/2001" terror act in the USA and a rapid securitization of migration afterwards, both in the USA and other western societies. This is to say that now the security notion of migration does not include just societal fears (such as, thinking of migrant as a threat to labor and domestic market stability, as a job-thief who costs more money to a state budget rather than contribution, and as a human who makes domestic society the worst place to live by affecting the welfare system), but it also encompasses border and organized crimes, terror attacks, drug and weapon trafficking and so on. The idea of "circular migration" which focused on meeting the labor shortages of western economies, from realist view-point, would be perceived as a product of these security notions. At this point very logical counter argument can appear by arguing that realism is a theory which can explain non-cooperation and conflicting situations and thus, it is an inadequate theoretical approach to explain an increasing cooperation at the regional and global level within the framework of the global migration 
governance. However, taking into account the above mentioned arguments, the realist scholars would claim that the ad-hoc informal institutions arranged for the international migration policy debates are not able to constrain sovereignty of nation states as the formal institutional arrangements of climate change, trade and health more or less do. Therefore, these informal inter-regional and global institutions, most of which are established exactly by powerful western states, from the realist view-point, let the powerful states reinforce asymmetric power distribution between them and migrant sending week countries, and give them opportunities to put on the table their perceived economic and security interests. To explain it more, when and where security and economic interests of powerful states concerning migration discussions are best met through collaboration, they probably give a preference to cooperation; but when these interests are best met through independent policies or bilateral cooperation, they avoid from international cooperation.

And finally, the realist argument about the dominance of security and economic interest over human rights in the foreign policy choices of rational nation-states can easily be observed in the politics of international migration. As it has been mentioned in the third chapter, none of migrant receiving developed countries ratified the UN's 1990 MWC, which focused on the promotion of fundamental human rights of migrants, even though 21 years have passed since it was adopted. The protests of the developed countries against the inclusion of the GFMD into the UN system, which has an international regime for the protecting of human rights, is another fact, which proves that states view migration mostly from the angle of security and economic interests, and human rights of migrants possess very small corner in the global policy discussions of migration.

To summarize the above mentioned considerations of realism about the international migration politics, the answer to the question of why international migration is governed as it is today would be as follows: In the anarchical environment, where migration has been highly securitized, the self-determined rational states worry about their security notions and they attempt to maximize their economic benefits without damaging their security interests. This requires from them not to sacrifice their sovereignty over the control of migration by establishing institutional global arrangements based on the formal structures, since there is a 
fear that the latter would constrain their sovereignty over migration issues by forcing them to implement normative and legally binding decisions of an international migration regime. And here the economic and political power distribution between powerful and week states let the former hinder the establishment of such global institutions/international migration regime and benefit from the ad-hoc institutions of international migration.

\subsection{Institutionalist approach}

Institutionalism has become very prominent theoretical approach in the realm of contemporary international relations, where International Institutions play a very important role. Its theoretical assumptions have been utilized by many scholars of political and social sciences to analyze the question of why states create institutions and international regimes, and what the latter can generate for societies. Therefore, institutionalism can offer some analytical tools to understand the state of the existing global migration governance and its institutions. To make the rest of the discussion comprehendible, there is a need to go through the general assumptions of the institutionalist approach on the international politics.

Institutionalism, like realism, agrees that states are self-interested and goal oriented actors who attempt to maximize their outcomes. They also agree that states act in an anarchical system of international relations, and this influences states' behavior. This is to say that institutionalism also views international politics as a "zero sum game", which means that the outcome of one state is equal to the loss of another state. However, concerning the establishment of international regimes, institutionalism (Rational-choice institutionalism) claims that states enter cooperation and form institutions because the latter diminish the transaction costs (making a rule, monitoring its implementation and forcing a commitment) and let states overcome the problem of cooperation - "prisoner's dilemma", where a state is insecure to cooperate because of the threat of cheating by another state. (Jönson and Tallberg, 2006: p. 5). In contrast to realist scholars, who claim that international institutions are embedded with power distribution and hence they generate outcomes only to powerful states, institutionalism

argue that once states establish institutions, the latter become autonomous and capable of shaping, even altering (Normative Institutionalism) the policies of states. (Keohane and Martin, 
1995: p. 46-51). We can describe the relationship between a state and an international regime, from the view-points of both realism and institutionalism in the following way:

A) Realist approach of International regime

A)

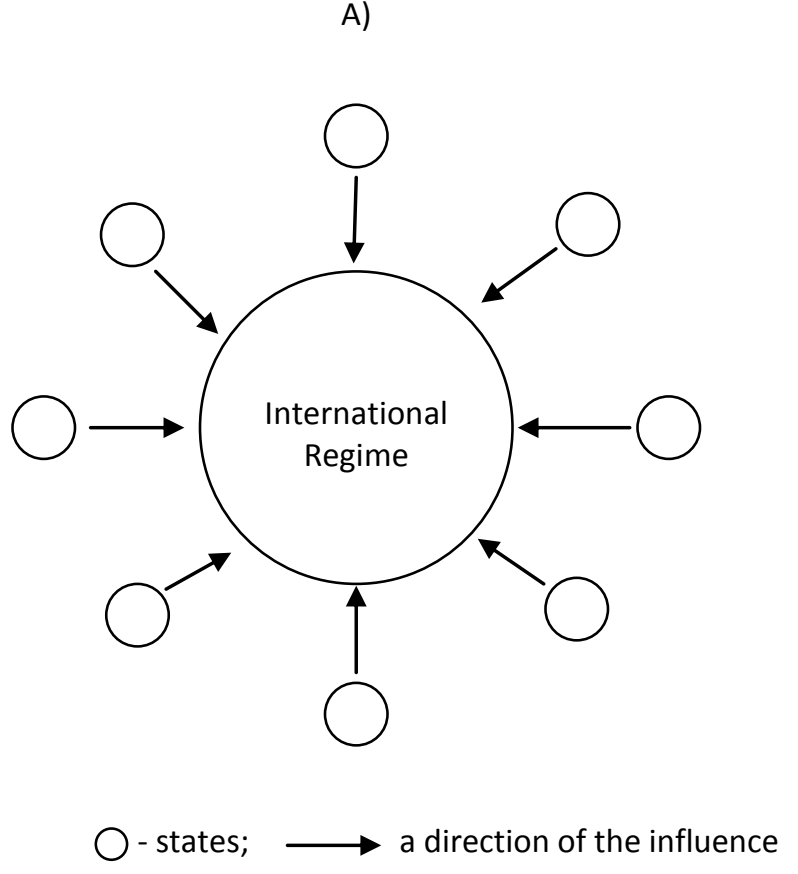

vs.

B) Institutionalist approach of International regime
B)

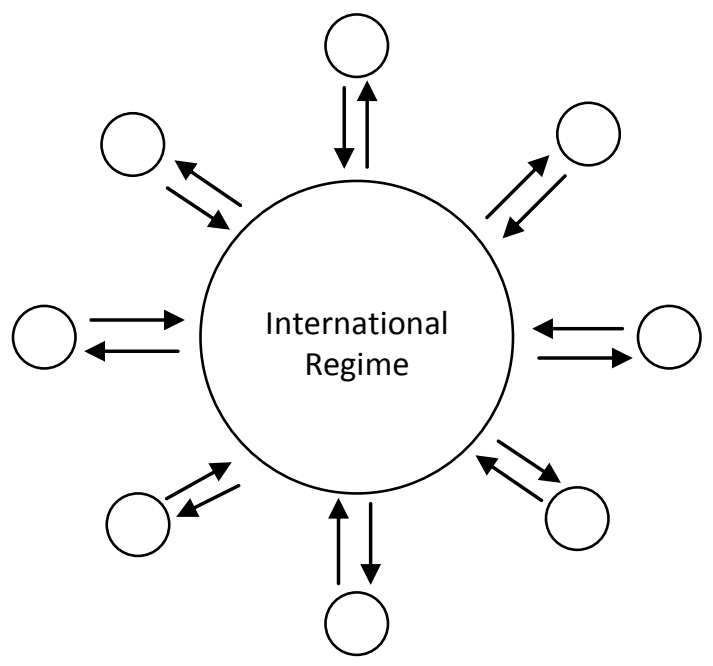

This is to say that in contrast to realism, who views institutions and regimes as dependent variables, institutionalism assumes international institutions and regimes to be both dependent variables in the sense that they are created by states and independent variables in the sense that they become autonomous after a while and have an effect on states, which have constituted them. Moreover, they claim that international regimes with their normative rules and decisions can generate outcome for every participant states, not just for powerful states. One more attribute to be mentioned, in contrast to thee realist scholars, who predict a pessimist future of international politics and institutions, the institutionalists thinkers believe in the possibility of cooperation and the importance and effectiveness of international institutions and regimes. From the view-point of the historical institutionalism, political choices which are made by earlier generations create institutions, which shape both policies and ideas for later generations (Meyers, 2000: p. 1261). 
When it comes to the area of international migration, the institutionalist arguments are partially applicable. Institutionalism is applicable to explain a highly institutionalized global governance of refugees, asylum seeker sand displaced people's flow through the international regime within the UN system, and labor migration through the international labor regime of the ILO. Taking into account the above mentioned arguments, the institutionalist scholars would claim that international regime of refugees and asylum protection was not established in a vacuum. They would rather argue that states have been major actors who formed this regime because of two main reasons: first, to diminish the transaction cost of dealing with refuges and asylum seekers and second, to overcome the insecurity problem (prisoner's dilemma) of cooperation in anarchical system of international migration politics. To put it with other words, states believed that international regime and its institutions could lessen the degree of the fear of cheating and push member states for further cooperation in order to gain joint outcomes and avoid joint losses in this policy area. According to institutionalism, once international regime of refugees and asylum protection established, it became autonomous and gradually shaped the policy choices of member states, regardless the degree of their power. As a matter of fact, today, 147 member states of the United Nations are parties to the 1951 UN Convention on the status of refugees and 1976 Protocol. These arguments are also applicable to the international regime of labor migration, where member states have to implement legallybinding decisions of the ILO. From the institutionalist view-point we can assume that both the international refugee regime and international labor regime provide reliable institutionalized information which make states to be sure that other states are not cheating, reduce transaction cost of dealing with these migration issues in isolation, point out credible results of monitoring of states' commitments and finally, attach a sense of reciprocity onto cooperation.

The common external immigration policy of the EU towards the nationals of the third world countries is the best example to the institutionalist approach of how supranational bodies of the EU promoted a common immigration policy for its sovereign member states. To put it in other words, sovereignty of member states over their independent migration policies has gradually been transferred to the EU, where the common rules and principles in the 
supranational level have been adopted and transferred back to the domestic level and implemented by the nation states.

However, if we take into account the empirical realities in the area of management of irregular migration and the human rights of migrants in transit and hosting countries, then the institutionalist approach breaks down. To give a very obvious example, the United Nations MWC has been ratified by only 44 member states since its adoption, which means that the UNHCHR, as an international institution within the UN system, has not been able to shape the policies of its member states and to force them to ratify the Convention during the last two decades. Vice versa, developed and powerful states of North have been able to pursue their economic and security interests as independent variables within this international institution.

To summarize the above mentioned considerations of institutionalism on the international migration politics and its institutions, in contrast to realism, institutionalism has not been able to give a clear answer to the question of why international migration is governed as it is today. While they partly agree with the realist assumption that interests of rational states have been key fact in determining the picture of nowadays international migration

politics, they predict a positive future about the global governance of migration. According to institutionalism, today, states have already started cooperation at the regional and global level (where they cannot step back because of the policy choices of their earlier generations), which will finally lead to the establishment of an international migration regime capable of shaping the behavior and policies of rational states.

\subsection{Chapter summary}

The aim of the chapter was to examine the theoretical arguments of two actor-oriented IR theories - Realism and Institutionalism in the area of international migration politics and to find out which theory can best explain the picture of the existing global governance of migration. Now, we can briefly summarize the realist and institutionalist approaches of international migration politics in the following structure. 


\begin{tabular}{l} 
Realism \\
\hline 1. States are the most important and \\
only decisive actors of international migration \\
politics
\end{tabular}

2. Cooperation is the least possible in a competitive anarchical system of international migration, where states act as self-interested rational actors based on their security and economy interests

3. International Institutions (both formal and informal) are established out of national interests of powerful migrant receiving states, and they are tools of powerful states to pursue their interests in a legal way. They are dependent on powerful states' interests and decisions

4. International regimes generate outcomes only for powerful states
Institutionalism

1. States do hold an important role in international politics of migration, but they are not the only actors

2. States do act as rational actors in anarchic system of international migration and focus mostly on their benefits, but cooperation is always possible

3. International Institutions are established to overcome the problem of prisoners' dilemma and to gain joint benefits from the management of migration. They are autonomous actors and capable of shaping the behavior of states (UNHCR, ILO)

4. International Regimes can generate outcomes for each participant state of cooperation

After all, we should agree on one point that in the age of globalization, where the enormous planet is treated as if it was a very small, there is a possibility of being a migrant for each of us, regardless a regular or irregular migrant, a tourist who wants to explore the cultural diversity of new countries or a miserable man running away from disasters hoping to get a refugee or asylum protection, a student who seeks an education to build up a professional career or a man who is in need of any job to get his/her stomach full. In that sense, as a human being attached to moral values, we would like the institutioalist approach of international relations to be applicable to the international politics of migration, and hence we would favor for the establishment of an international migration regime, which would be able to guarantee a respect to human rights and to ease the flow of people without any restrictions like commodities, capital and services. However, if take into account the empirical data stated in this project and compare the rationality (pessimist forecast) of realism against institutionalism (optimistic forecast), we would see that institutionalism have lost considerable rationale in the area of international migration politics. Thus, even though it can say too much about the highly 
institutionalized global governance of climate change, trade and health, where international institutions and regimes, as independent variables, maintain considerable effects on states behavior, Institutionalism is mostly an inadequate theoretical approach to explain the international migration politics, with the exclusion of refugees and asylum protection (which also have some shortcomings) and labor migration, and hence, its optimistic forecast, unfortunately, does not seem to be reliable. 


\section{CHAPTER SIX}

\section{CONCLUSION}

The overriding concern of this research project has been to explore the nascent global governance of migration and to understand the logic behind the politics of international migration based on the theoretical implications. To this end, first, chapter two has mapped out the actors of the global migration governance by studying them under two headlines: Formal and Informal governance. The crucial findings of the chapter was that the formal governance, where international cooperation and debates take place within the international institutions based on formal structures, is noticeably week and fragmented. We have noticed that despite the fact that nation states understand the difficulty of dealing alone with the international migration, which has become one of the most trans-boundary issue in the international relations due to the impacts of globalization, they are still not eager to sacrifice their autonomies over their sovereign migration politics and to establish an institutionalized international regime for the management of migration. Therefore, with the exclusion of the international refugee and international labor regime, today, the international migration is highly characterized with the absence of a universal intergovernmental organization, which would have been able to produce normative decisions, norms and rules, like the WTO in the global trade governance or the WHO in the global health governance do. The International Organization for Migration, which is the only intergovernmental organization that covers all patterns of international migration, is an operational and service-providing institution rather than a normative decision-making organization. In the absence of an institutional cooperation states prefer to cooperate through informal (ad-hoc) inter-regional and global arrangements, which do not impose any legal responsibilities on states and let the latter take a selective approach towards the migration. All of these are to say that the global governance of migration is characterized with a highly informal "bottom-up" structure rather than a treaty based "topdown" structure. 
Second, chapter three has examined the empirical viability of the potential civil society contributions to the global governance institutions of the international migration, since civil society actors, in general, are assumed to be able to address the shortcomings of the global governance institutions by increasing the public participation, giving the voice to those who are affected and by pushing international institutions to be more transparent and accountable. The chapter has found out that the civil society participation in the politics of international migration, concerning both the quality and quantity, is the least developed in comparison to other trans-boundary issue areas, such as trade, climate change and health, and therefore, we are not able to notice the above mentioned civil society contributions to the global governance of migration. The chapter argues that it has two main reasons. First, the access granted to them by the global arrangements of the international migration is very limited and they are mostly welcomed to the policy discussions as observers. Second, most of civil society actors involved in the politics of international migration are operational actors, which focus on service delivery and pedagogical work to marginalized migrants, and those who are involved in advocacy work and have access to the policy discussions within the global arrangements cover only one aspect of international migration, mostly focusing on human rights of migrants. All of these are to say that civil society actors involved in the politics of international migration, in most cases, do not have chances to participate in the decision-making stage of international cooperation and they are far away from making the above mentioned contributions to the governance of this policy issue.

Third, the fourth chapter has outlined the major factors that have made the global governance of trade, health and climate change noticeably successful in comparison to international migration, which have got more or less the same level of trans-boundary nature like those global policy issues. The chapter has concluded that in order to achieve the same level of success in the global governance of migration there is a need, first, to attach a topdown treaty based structure to the politics of international migration by incorporation of the IOM into the United Nations system, which would probably let the IOM transform from an operational institution to a decision-making organization. And second, there is a need to 
enlarge the space for civil society participation, mostly for advocacy work in t decision-making stage, in the global governance institutions of migration.

Finally, chapter five has outlined the concluding analysis from the view-points of two actor-oriented theories of international relations which help us to understand the logic behind the politics of international migration. Actor-oriented IR theories - realism and institutionalism, which share the similar position concerning the role of states in the anarchical system of international states, confront each others when it comes to explain the relationship between states and international regimes and the effectiveness of the latter. From this perspective, I have explained the politics of international migration in a comparative way by putting realism versus institutionalism and finally, concluded that the pessimist outline of the realist approach is the dominant IR theory which best explains the real picture of the global migration governance. Mixing the empirical realities with the theoretical implications of realism, the following can be derived from this analysis:

- The notion of sovereignty is still the dominant factor that shapes the migration politics of nation states, and hinders the establishment of an international migration regime which would have been able to enforce universal norms and principles for the management of migration;

- Migration is viewed as a threat to the stability and welfare in many migrant receiving western societies, which pushes nation states to give a preference to their security interests rather than economic concerns or human rights of migrants;

- It is mainly migrant receiving developed countries of the economic North that determine and shape both the flows of people and the politics of international migration by moving towards more and more restrictive migration policies.

- Existing formal and informal institutions have had little impact on the politics of international migration even though the latter has always been in the limelight of the global policy concerns across various forums, international commissions and dialogues. 
- And finally, in the short run, states will probably not enter into binding forms of cooperation, or they will not establish an international regime for migration.

However, these should not let us assume a totally pessimistic future for the global governance of migration. None of the problems are impossible to solve, if there is a will to do so. To make some predictions on the future of international migration management, we should not forget that history is full of with unexpected events. No one could have been able to predict that two historical enemies in Europe - Germany and France - one day would come together and lay down the foundations of nowadays supranational international organization European Union. No one, 50-60 years ago, would think of nowadays international climate change regime or international trade regime. Or no one could imagine what have happened in the international migration during the last 40-50 years. We should also not forget that international migration started to take a corner at the global policy agenda at the beginning of the $21^{\text {st }}$ century, and only a decade has passed since, which has not been enough for the establishment of an international regime for such a complex social phenomenon. It is very difficult to know what will happen 40-50 years into the future from now. We cannot predict whether there will be natural disasters or terrible wars that would produce refugees or displaced people which would count for the international migration. However, we can be sure that within the context of ongoing globalization international migration will be driven by labor demand. As it has been stated in the final report of the GCIM, "the number of people seeking to migrate from one country and continent to another will increase in the years to come, due to developmental and demographic disparities, as well as differences in the quality of governance" (GCIM, 2005: p. 12). Therefore, migrant receiving states will probably think of softening their restrictive migration policies and moving towards a single migration regime. From the historical perspective, it will happen, but unfortunately not in the short run. What should be in the limelight of the future cooperation on the international migration is that a migrant, regardless of regular or irregular, is a human being with moral particularities and entitled human rights, rather than being a material source, which can be exported or imported like bananas, computer or car according to the political and economic needs of the receiving country. This is to say that 
migration should not be extremely viewed from the economic angle in the future cooperation unlike it is viewed today, and instead the human rights angle should be given a preference over the economic and security concerns.

This research has studied the politics of international migration of the last decade and stressed out that the realist assumption of the international relations has so far been the dominant approach in this policy area. The obvious problem with this research is that it has encompassed a very short period and therefore, it would be advisable to see, in future researches, how the politics of international migration will look like in a decade or so from now, or whether the states' choices among their security, economic and human rights concerns will change or stay the same when it comes to the management of international migration. Moreover, if an international migration regime is established, future researches should focus on the facts and reasons that lead to the establishment of such a regime. 


\section{REFERENCE LIST}

\section{Books and articles:}

1. Alexander Betts (2008), Global Migration Governance. GEG Working Paper 43

2. Alexander Betts (2011), Global Migration Governance (Oxford: Oxford University Press)

3. Bernauer Thomas and Schaffer L. Maria (2010), Climate Change Governance. IED Working Paper 12

4. Bertrand B., Brauman B., Decaux E., Devin G. \& Wihtol de Wenden C. (2008), Migration: A New Perspective - Bulding Global Democracy (Editions La Decouverte, Paris)

5. Bhagwati Jagdish (2004), In Defense of Globalization (Oxford: Oxford University Press)

6. Castles Stephen (2004), "In the next 50 years what will be the shape of politics, policy and governance in respect to international migration?", in GCIM Working Paper (Oxford, 2004)

7. Channac Frederique (2007), "Global or International Governance for Migration? Building up Co-operation and Enhancing Multilateralism from Regional to Global Level". GARNET Working Paper: No. 19/07

8. De Jonge Oudraat C. and Haufler V. (2008), "Global Governance and the Role of NGOs in International Peace and Security". American Institute for Contemporary German Studies Policy Report 33

9. Della Porta, Donatello \& Micael Keating (2008), Approaches and Methodologies in the Social Sciences: A Pluralist Perspective (Cambridge: Cambridge University Press)

10. Dogson Richard, Lee Kelley and Drager Nick (2002), Global Health Governance: A Conceptual Review (Center on Global Change \& Health, London)

11. Dunne Tim, Kurki Milja and Smith Steve (2007), International Relations Theories: Discipline and Diversity (Oxford: Oxford University Press)

12. Florini Ann M. (2000), The Third Force: The Rise of Civil Society (Washington DC: Brookings) 
13. Finnemore Martha and Sikking Kathryn (1998), "International Norm Dynamics and Political Change". International Organization, Vol. 52, No. 4, pp. 887-917.

14. Fries Tom and Peter Walkenhorst (2010), Sharing Global Governance: The Role of Civil Society Organizations (Washington, DC/Gütersloh, Germany)

15. Ghosh Bimal (2005), Managing Migration: Whither the Missing Regime (Draft article of the Migration without borders series, UNESCO document)

16. Gordon Jenifer (2010), "People Are Not Bananas: How Immigration Differs From Trade". Nothwestern Univeersity Law Review, Vol. 104, No. 3, pp. 1109-1145.

17. Green Jessica F. and Thouez Colleen (2005), Global Governance for Migration and the Environment: what can we learn from each others?. Global Migration Perspectives No. 46 (GCIM, Geneva)

18. Green Jessica F (2010), "Private Standards in Climate Regime: The Greenhouse Gas Protocol". Business and Politics, Vol. 12: Iss. 3, Article 3

19. Grugel Jean B. and Piper Nicola (2007), Critical Perspectives on Global Governance: Rights and Regulation in Governing Regimes (London: Routledge)

20. Held D. and McGrew A. (2002), Governing Globalization: Power, Authority and Global Governance (Polity Press)

21. Jönson Christer and Tallberg Jonas (2008), "Institutional Theory in International Relations", in Jon Pierre, Guy Peters and Gerry Stoker (2008), Debating Institutionalism (Manchester and New York, Manchester University Press)

22. Jorgensen Knud Erik (2010), International Relations Theory - A New Introduction (Basingstoke: Palgavre Macmillan)

23. Kaldor Mary (2003), Global Civil Society: An Answer to War (Polity Press, Cambride)

24. Kalm Sara (2008), Governing Global Migration (Lund University, Department of Political Science)

25. Kalm Sara and Piper Nicola (2010), Global Governance of Migration and The Migrants Rights Movement (Lund University and Swansea University)

26. Karns Margaret P. and Mignst Karen A. (2004), International Organizations: The Politics and Processes of Global Governance (Lynne Rienneer Publishers, Boulder) 
27. Keck Margaret E. (2004), "Governance Regimes and the Politics of Discursive Representation", in Nicola Piper and Anders Uhlin (eds.) Transnational Activism in Asia: Problems of Power and Democracy (London, Routldge)

28. Keohane Robert O. and Martin Lisa L. (1995), "The Promise of Institutionalist Theory". International Security, Vol. 20, No. 1, pp. 39-51

29. Klein Solomon M. (2005), International Migration Managmenet Through Inter-State Consulation Mechanism: Focus on Regional Consultative Process on Migration. IOM Working Paper

30. Klekowski von Koppenfels Amanda (2001), The Role of Regional Consultative Process in Managing International Migration. IOM Migration Reseacrh Series, No. 3 (IOM, Geneva)

31. Lee Kelley, Srihdar Devi and Patel Mayur (2009), "Bridging the Divide: Global Governance of Trade and Health". The Lancet, 373, 9661, pp. 416-422

32. Lee Kelley (2010), "Civil Society Organization and The Functions of Global Health Governance: What Role within Intergovernmental Organizations?". Globa Health Governance, Vol. III, No. 2, pp. 1-20.

33. Lipschutz Ronnie (1992), "Reconstructing World Politics: The Emergence of Global Civil Society". Millenium - A Journal of International Studies, Vol. 21, pp. 39-420.

34. Martin Susan (2005), The Legal and Normative Framework for International Migration, GCIM: Thematic Studies

35. Meyer Florian (2010) "Is there is such a thing as Global Governance? Can it ever be effective?" (University of Birmingham)

36. Meyers Eytan, (Winter, 2000) "Theories of International Immigration Policy - A comprehensive anaylsis". International Migration Review, Vol. 34, No. 4, pp. 1245-1282.

37. Najam Adil, Papa Michaela and Taiab Nadaa (2006), Global Environmental Governance: A Reform Agenda (Winnipeg, Manibota)

38. Newland Kathleen (2002), The Governance of International Migration: mechanisms, processes and institutions (Migration Policy Institute)

39. Nuscheler Franz (2003), "Civil Society Actors: A Democratic Corrective for International Organization?" (Friedrich-Ebert-Stiftung, Berlin)

40. Pattberg Phillipp (2006), "Global Governance: Reconstructing a Contested Social Science Concept". GARNET Working Paper No. 04/06 
41. Piper Nicola (2007), "Governance of Migration and Transnationalisation of Migrants' Rights - An Organizational Perspective". COMCAD Arbeitspapiere - Working Paper No. 22 (Swansea University)

42. Risse Thomas (2002), "Transnational Actors and World Politics", in Walter Carlsnaes, Thomas Risse and Beteh A. Simmons (eds.), Handbook of International Relations (London: Sage)

43. Rittberger Volker (2001), Global Governance and The United Nations System (United Nations University Press)

44. Rittberger Volker \& Bernard Zangl with Matthias Staisch (2006), International Organization: Polity, Politics and Policies (Houndmills: Palgrave Macmillan).

45. Robinson Mark and White Gordon (1997), "The Role of Civic Organizations in the Provision of Social Services: Towards Synergy". Reserach for Action 37, World Institute for Development Economic Reseacrh (Helsinki)

46. Rosenau James N. and Durfee Mary (2000), Thinking Theory Throughly: Coherent Approaches to an Incoherent World (Westview Press)

47. Scholte, J.A. (2002) "Civil Society and Democracy in Global Governance". Global Governance, vol. 8, no. 3 (July-September), pp. 281-304.

48. Scholte, J.A. (2007) "Civil Society and the Legitimation of Global Governance". CSGR Working Paper 223/07 (March), pp. 1-41.

49. Scholte, J.A. (2011) Building Global Democracy? Civil Society and Accountable Global Governance (Cambridge: Cambridge University Press)

50. Steffek Jens and Nanz Patrizia (2008), "Emergent Patterns of Civil Society Participation in Global and European Governance", in Steffek Jens, Kissling Claudia and Nanz Patrizia (eds.), Civil Society Paricipation in European and Global Governance. A Cure for the Democratic Deficit? (Basingstoke: Palgavre)

51. Steffek Jens and Ehling Ulrike (2008), "Civil Society Participation at the Margins: The Case of the WTO", in Steffek Jens, Kissling Claudia and Nanz Patrizia (eds.), Civil Society Paricipation in European and Global Governance. A Cure for the Democratic Deficit? (Basingstoke: Palgavre)

52. Steffek Jens (2010), "Explaining Patterns of Translational Participation: The Role of Policy Fields", in Christer Jönsson and Jonas Tallberg (eds.), Transnational Actors in Global Governance: Patterns, Explanations, and Implications (Basingstoke: Palgavre) 
53. Tallberg Johans and Uhlin Anders (2011), "Civil Society and Global Democracy : An Assessment", in Archibugi Daniele, Koeing Archibugi Mathias and Marchetti Raffaele (2011), Global Democracy: Normative and Empirical Perspectives (Cambridge University Press)

54. Tanner Arno (2006), The future of Inernational Migration Governance: A Survey of Subject Priorities in a New Organizational Model (Helsinki, East-West Books)

55. Tarrow Sidney (2001), "Transnational Politics: Contention and Institutions in International Politics". Annual Review of Political Science, Vol. 4, No. 1, pp. 1-20.

56. Taylor Charles (1995), "Liberal Politics and Public Sphere", in Taylor Charles Philosophical Arguments (Harward University Press)

57. Thouez Colleen (2003), The Role of Civil Society in Shaping International Migration Policy (Duke Univerity)

58. Van Rooy Alison (1998), Civil Society and the Aid Industry: The Politics and Promise (Earthsan Publications Ltd, London)

59. Vogler John (1995), The Global Commons: A Regime Analyses (John Wiley \& Sons LTD, Chichester)

60. Wapner Pauk (1995), "Politics Beyond the State: Environmental Activism and World Civic Politics". World Politics, April, pp. 311-340.

61. Youngs Gillian (1999), International Relations in a Global Age: A Conseptual Challange (Polity Press, Cambridge)

62. Zolberg, A.R. (1989), "The Next Waves: Migration Theory for a Changing World". International Migration Review, 23 (3), pp. 403-430.

\section{Other sources:}

63. Commission on Global Govercance (1995), Our Global Neighborhood, accessed on february 26, 2011 at http://www.reformwatch.net/fitxers/168.pdf

64. December 18 (2009), Annual Report, accessed on April 10, 2011 at http://www.december18.net/sites/default/files/AnnualReport2009-Final.pdf 
65. GFDM (2007), Report of the first meeting of The Global Forum On Migration and Development (Brussels), accessed on March 27, 2011 at http://www.gfmd.org/en/gfmdmeetings/brussels-2007.html

66. GFMD (2008), Protecting and Empowering Migrants for Development (Manila), accessed on March 27, 2011 at http://www.gfmd.org/en/gfmd-meetings/manila-2008.html

67. GFMD (2010), Statement of Civil Society Days (Puerto Vallarta), accesed on April 13, 2011 at http://www.gfmd.org/en/process/civil-society.html

68. Guardian (2011), "Boat trying to reach Lampedusa was left to drift in Mediterranean for 16 day, despite alarm being raised", by Jack Shenker in guardian.co.uk. Accessed on May 9, 2011 at http://www.guardian.co.uk/world/2011/may/08/nato-ship-libyan-migrants

69. Global Migration Governance (2006), Terms of Reference, accessed on March 27, 2011 at http://www.globalmigrationgroup.org/tor.htm

70. Human Rights Watch (2010), Rights on the line (New York: HRW), accessed on April 12, 2011 at http://www.hrw.org/en/reports/2010/12/12/rights-line-0

71. ILO (1997), The Constitution of the International Labor Organization, accessed on March 24, 2011 at http://www.ilo.org/ilolex/english/constq.htm

72. ILO (2004:A), A Fair Globalization: Creating Opportunities for All, World Commission on the Social Dimension of Globalization, International Labor Office, Geneva. Accessed on March 24, 2011 at http://www.ilo.org/public/english/wcsdg/docs/report.pdf

73. ILO (2004:B), Report VI: Towards a fair deal for migrant workers in the global economy, 92nd session of International Labor Conference, Geneva. Accessed on March 24, 2011, at http://www.ilo.org/public/english/standards/relm/ilc/ilc92/pdf/rep-vi.pdf

74. IOM (1989), The Constitution of the International Organization for Migration, accessed on March 24, 2011 at http://iom.int/jahia/Jahia/about-iom/constitution/lang/en

75. Kirpatrick Holly, "Global Governance and Migration: Towards a Normative, Migratory Framework", accessed on February 26, 2011 at http://www.guyanajournal.com/migrant.html

76. "Migration and Globalization" (2010), a project of the Levin Institute (The State University of New York), accessed on February 26, 2011 at http://www.globalization101.org/uploads/File/Migration/migration2010.pdf 
77. United Nations (2002), Strengthening the United Nations: an agenda for further chane, Report of the Secretary-General (A/57/387), accessed on February 23, 2011 at http://www.un.org/largerfreedom/chap5.htm

78. United Nations (2004), Globalization and interdependence: international migration and development, A/59/485/Add.2, acessed on March 25, 2011 at http://daccess-ddsny.un.org/doc/UNDOC/GEN/N04/648/93/PDF/N0464893.pdf?OpenElement

79. United Nations (2006), Summary of the High-Level Dialogue on International Migration and Development, A/61/515, accessed on March 25, 2011, http://daccess-dds ny.un.org/doc/UNDOC/GEN/N06/571/02/PDF/N0657102.pdf?OpenElement

80. United Nations High Commissioner for Refugees (2011), "States Parties to 1951 Convention relating to the Status of Refugees and the1967 Protocol", accessed on April 12, 2011 at http://www.unhcr.org/3b73b0d63.html

\section{Useful homepages:}

http://www.gfmd.org

GFMD: Global Forum on Migration and Development

http://www.globalmigrationgroup.org

GMG: Global Migration Group

http://www.gcim.org

GCIM: Global Commission on International Migration

http://www.iom.int

IOM: International Organization for Migration

http://www.ilo.org

ILO: International Labor Organization

http://www.migrantwatch.org

MRI: Migrants Rights International

http://www.hrw.org

HRW: Human Rights Watch

http://www.mfasia.org

MFA: Migrants Forum in Asia

http://www.december18.net 
“December 18”

http://www.un.org

UN: United Nations

http://www.unhcr.org

UNHCR: United Nations High Commissioner for Refugees

http://www.ohchr.org

UNHCHR: United Nations Office of the High Commissioner for Human Rights

http://www.unfpa.org

UNFPA: United Nations Population Fund 